\title{
Microvariação na sintaxe dos clíticos: os dialetos portugueses dos Açores e Madeira
}

\section{Microvariation in the syntax of clitics: the Portuguese dialects of Azores and Madeira}

\author{
Ana Maria Martins \\ Centro de Linguistica, Faculdade de Letras, Universidade de Lisboa, Alameda da Universidade, 1600- \\ 214 Lisboa, Portugal \\ anamartins@letras.ulisboa.pt \\ http://orcid.org/0000-0003-0589-5109
}

Recibido o 05/07/2020

Aceptado o 08/02/2021

\section{Resumo}

Este artigo estuda a colocação dos pronomes clíticos nos dialetos portugueses dos Açores e Madeira. A base empírica é o Corpus dialetal para o estudo da sintaxe (CORDIAL-SIN). Uma primeira abordagem panorâmica mostra que estes dialetos apresentam tipicamente o padrão geral de colocação dos clíticos do portugués europeu, mas admitem igualmente colocaçóes atípicas, com expressão quantitativa significativa. A investigação foca-se depois em dois tipos de colocação atípica: a ênclise ao verbo finito em configuraçóes sintáticas tipicamente indutoras de colocação proclítica; e a próclise a formas não finitas do verbo em configuraçôes sintáticas onde, tipicamente, se esperaría a ênclise. Os dois tipos de colocação atípica são analisados na sua expressão quantitativa, distribuição geográfica e distribuição por estruturas sintáticas, mostrando-se a ênclise atípica especialmente produtiva com certos advérbios (até, também) e nas oraçôes relativas (resuntivas e cortadoras). Numa perspetiva geolingüística, as nove ilhas dos Açores apresentam uma relativa homogeneidade, não sendo possível identificar, de forma consistente, subáreas dialetais. Já no arquipélago da Madeira observa-se uma clara separação entre a ilha da Madeira (representada no CORDIAL-SIN por Câmara de Lobos e Caniçal) e a ilha de Porto Santo, em particular a Camacha. A Madeira destaca-se pela forte incidência da ênclise atípica nas frases finitas e Porto Santo pela incidência da próclise atípica nas frases com infinitivo e gerúndio. Globalmente, a ênclise atípica está mais representada no corpus em número de ocorrências, mas a próclise atípica é percentualmente mais expressiva e tem paralelo em factos conhecidos das variedades não europeias do portugués. Os fenómenos de interpolação e reduplicação do clítico são também considerados.

\section{Palavras chave}

sintaxe, variação, dialetos, clíticos, ênclise atípica, próclise atípica, Açores, Madeira, português europeu, portugués em África e no Brasil

\begin{abstract}
This article studies clitic placement in the Portuguese dialects of Azores and Madeira. Its empirical basis is the Syntax-oriented corpus of Portuguese dialects (CORDIAL-SIN). An initial descriptive overview shows that these dialects typically display the general European Portuguese pattern of clitic placement, but they also admit atypical instances of clitic placement, with significant quantitative expression. The investigation then focuses on two types of atypical placement: enclisis to the finite verb in syntactic configurations typically inducing proclitic placement; and proclisis to the non-finite forms of the verb in configurations where enclisis would be expected. The two types of atypical placement are analyzed in their quantitative expression, geographic distribution, and distribution across syntactic structures, which reveals that atypical enclisis is especially productive with certain adverbs (até, também) and in (resumptive/chopping) relative clauses. From a geolinguistic perspective, the nine islands of Azores display relative homogeneity, thus the data do not suggest any consistent split into smaller dialectal subareas. On the contrary, the Madeira archipelago shows a clear split between the island of Madeira (represented in CORDIAL-SIN by Câmara de Lobos and Caniçal) and the island of Porto Santo (mainly represented by Camacha). The island of Madeira stands out for the strong incidence of atypical enclisis in finite clauses, and Porto Santo for the incidence of atypical proclisis in infinitival and gerund structures. Globally, atypical enclisis has a stronger presence in the corpus in absolute number of occurrences, but atypical proclisis is more expressive in percentage of occurrences and has correlates in non-European varieties of Portuguese. The phenomena of interpolation and clitic reduplication are also considered.
\end{abstract}

\section{Key words}

syntax, language variation, dialects, clitics, atypical enclisis, atypical proclisis, Azores, Madeira, European Portuguese, Portuguese in Africa and Brazil 


\section{Sumário}

1. Introdução. 2. Próclise, ênclise, reduplicação e interpolação nos dialetos açorianos e madeirenses. 3. Microvariação na distribuição da ênclise atípica: Açores, Madeira, Porto Santo. 4. Próclise atípica: infinitivo, gerúndio e particípio passado. Alguns dados comparativos 5. Conclusão: variação, estabilidade e mudança linguísticas.

\section{Contents}

1. Introduction. 2. Proclisis, enclisis, reduplication and interpolation in the dialects of Azores and Madeira. 3. Microvariation in the distribution of atypical enclisis: Azores, Madeira, Porto Santo. 4. Atypical proclisis: infinitive, gerund and past participle. Some comparative data. 5. Conclusion: language variation, stability and change.

\section{Introdução}

$\mathrm{E}$ ste artigo ocupa-se da colocação dos pronomes clíticos (distribuição da próclise e da ênclise) nos dialetos portugueses dos arquipélagos dos Açores e da Madeira, de acordo com os dados do CORDIAL-SIN (Corpus Dialetal para o Estudo da Sintaxe). ${ }^{1} \mathrm{O}$ estudo é descritivo, mas funda-se nos pressupostos teóricos e concetuais da gramática generativa. Depois de uma breve apresentação do padrão dominante de colocação dos pronomes clíticos nestes dialetos, que se revela convergente com o que tem sido descrito como norma do português europeu (Duarte 2003; Martins 2013), o estudo foca-se nos dados atípicos, isto é aqueles que escapam ao padrão maioritário e têm no corpus, globalmente, uma frequência relativamente baixa, mas significativa (cf. tabela 1, na secção 2). Referir-me-ei a estes dados como atípicos, e não como dialetais por duas razões: por um lado são tão dialetais como os dados típicos, pois todos são parte da gramática dos dialetos estudados; por outro lado, enquanto não forem estudados, com método e perspetiva comparáveis, os dialetos portugueses continentais, não é possível saber se entre os dados atípicos alguns serão específicos dos dialetos açorianos ou madeirenses. ${ }^{2}$ Acresce que colocaçôes atípicas dos pronomes

1. O arquipélago dos Açores é composto por nove ilhas: de ocidente para oriente, Corvo, Flores, Faial, Pico, São Jorge, Graciosa, Terceira, São Miguel, Santa Maria. O arquipélago da Madeira é composto pelas ilhas da Madeira e de Porto Santo. Os onze pontos da rede do CORDIAL-SIN correspondentes aos arquipélagos dos Açores e da Madeira (um ponto por ilha) sáo os seguintes (número do ponto - código, ilha: localidade(s) [n ${ }^{\circ}$ de palavras no corpus]): 6 - CLC, Madeira: Câmara de Lobos e Caniçal [9.369 palavras]; 7 - PST, Porto Santo: Camacha e Tanque [9.791 palavras]; 9 - FLF, Flores: Fajāzinha e Costa do Lajedo [9.351 palavras]; 10 - MIG, São Miguel: Ponta Garça [19.801 palavras]; 20 - PIC, Pico: Bandeiras, Ribeiras, Ribeira do Meio e Madalena [26.904 palavras]; 23 - TRC, Terceira: Fontinhas, Biscoito, S. Brás, S. Mateus e Praia da Vitória [23.682 palavras]; 33 - CRV, Corvo: Vila do Corvo [19.881 palavras]; 34 - GRC, Graciosa: Santa Cruz da Graciosa, Covas e Carapacho [11.125 palavras]; 38 - CLH, São Jorge: Ribeira Seca (concelho de Calheta) [12.866 palavras]; 41 STE, Santa Maria: Santo Espírito e Pedras de S. Pedro [11.700 palavras]; 42 - CDR, Faial: Cedros [28.075 palavras]. O corpus CORDIAL-SIN é de acesso livre e pode ser descarregado a partir da página web do Centro de Linguística da Universidade de Lisboa (http://www.clul.ulisboa.pt/recurso/ cordial-sin-syntax-oriented-corpus-portuguese-dialects).

2. Um revisor sugere a substituiçáo dos termos típico e atípico por padrão e não-padrão. Prefiro manter os termos típico e atípico (comuns na área da aquisiçâao da linguagem e aqui trazidos para o domínio 
clíticos não são exclusivas dos dados dialetais, encontrando-se também no português europeu escrito, literário e jornalístico, como se exemplifica em (1) a (3). Em (1a-c) vemos ocorrências de enclíticos em oraçóes subordinadas finitas (completiva, consecutiva e clivada) que têm como padrão de colocação típico a próclise; ${ }^{3}$ também na frase (1d) há ênclise atípica por preceder o verbo o advérbio até. Nos exemplos de (2) ocorre a próclise em contextos tipicamente enclíticos (frases matriz afirmativas, sem itens indutores de próclise a preceder o verbo), incluindo a posição inicial de frase. Em (3) observam-se ocorrências de próclise em oraçôes infinitivas não introduzidas por preposição (3a-b) ou introduzidas pela preposição $a$ (3c-d), configuraçôes que são tipicamente enclíticas. Os exemplos em (4) mostram-nos a interpolação das palavras lá e já entre o proclítico e o verbo, embora as gramáticas de referência para o português nos digam que só a palavra nâo pode separar o clítico do verbo.

(1) a. O meu primo diz que lá elas lavam-se antes e depois. (Jorge de Sena, Sinais de Fogo. Martins 2013: 2277)

b. Fê-la girar no chão de terra e de ervas pisadas, com tanta violência que os membros estreitos da garota embrulharam-se uns nos outros como fios de esparguete. (António Lobo Antunes, Fado Alexandrino. Ibidem)

c. Mas o pior é que nesta dança repentina o corpo falha-lhe. (José Cardoso Pires, Hóspede de Job. Ibidem)

d. Eis uma tirada - penso para comigo - que se alguém se atrevesse a dizer em voz alta seria crucificado. E, de facto, até ela diz-me aquilo quase em segredo, tão baixinho que mal consigo ouvi-la e só depois de se certificar que não há ouvidos à porta do estabelecimento. (Expresso semanário, 28-06-2020, Miguel Sousa Tavares)

(2) a. Fã de "Billy Elliot" me declaro, mas se detestasse a obra a indignaçáo não seria menor (Expresso Curto, 25-06-2018, Pedro Cordeiro)

b. Eu vos garanto: não venho com luz ou gratidão (Expresso online, 0911-2017, Mariana Lima Cunha)

da variação linguística) por várias razóes: o uso do termo não-padrão para descrever traços gramaticais de variedades dialetais expressa preconceito linguístico; as colocaçôes atípicas dos pronomes clíticos ocorrem também na variedade padrão do português europeu (cf. os exemplos (1) a (4)); o termo atípico decorre de um critério objetivo e sem valoração negativa, indicando simplesmente que se trata da opção globalmente menos frequente e, em geral, com frequência relativamente baixa. Neste sentido, é também mais informativo do que o termo não-padrão.

3. A ênclise em oraçôes subordinadas, sobretudo completivas, ocorre em outras línguas ibéricas ocidentais cujo sistema de colocação dos pronomes clíticos é, em larga medida, idêntico ao do português europeu. É o caso do asturiano (González i Planas 2007, Fernández-Rubiera 2009a, 2009b, 2010) e do galego (Álvarez \& Xove 2002), sendo o asturiano a língua em que o padrão enclítico em subordinadas é mais comum. 
c. E vivemos hoje um dos mais conturbados momentos da história de duas décadas do Bloco. Se verá se com consequências eleitorais para o partido. (Expresso Curto, 01-08-2018, Martim Silva)

d. Elizabeth Warren ficou em terceiro lugar no seu próprio estado. Se verá se faz o que devia ter feito anteontem: desistir para o candidato mais bem colocado do campo progressista. (Expresso online, 04-03-2020, Daniel Oliveira)

(3) a. o pai cedo lamentou the ter saído na rifa descendência assim (Expresso, 20-02-2010, José Cutileiro)

b. Mas os estados têm, para o mal e para o bem, uma continuidade histórica que transcende os indivíduos $(. .$.$) - e da qual não podem se$ descartar para se eximir de responsabilidades. (Público, 12-06-2020, Rui Tavares)

c. Isto tem implicaçóes importantes para os partidos e pessoas que estejam determinados a se lhe opor. Expresso online, 10-10-2019, Alexandre Abreu)

d. O futebol é importante porque milhóes de pessoas lhe dáo importância. E ao lhe darem importância transportam para o fenómeno do futebol interesses políticos, sociais e económicos conflituantes que o tornam ainda mais relevante. (Expresso online, 23-05-2018, Daniel Oliveira)

(4) a. Quando se lá chega, chuta quem estiver em melhores condições (Expresso online, 27-06-2016, Nicolau Santos)

b. Quem não hesita em fazer uma coisa daquelas não tem com certeza, em privado, princípios que nos possam tranquilizar. Como de resto, se já constatou. (Público, 25-03-2011, Vasco Pulido Valente)

O que vemos nos dados extraídos do CORDIAL-SIN é uma amplitude maior de tais dados, quer na sua distribuição contextual quer, possivelmente, em frequência. ${ }^{4}$

A investigação de Magro $(2007,2010)$ mostrou que a ênclise atípica, a par dos fenómenos de interpolação e reduplicação, pode ser explicada como resultado de um processo de metátese morfológica (Harris e Halle 2005), ou seja, uma inversão pós-sintática da ordem das palavras (cf. secção 2, após tabela 5). Uma observação fina da colocaçáo dos pronomes clíticos nos dialetos açorianos e madeirenses sustenta a proposta de Magro, a qual náo parece cobrir, no entanto, todos os (aspetos dos) dados atípicos. Por um lado, não há só ênclise atípica, há também próclise atípica. Por outro lado, há uma maior concentração de ênclise atípica em contextos sintáticos particulares, o que a metátese morfológica, nos termos de Magro (2007, 2010), seguindo

4. Digo possivelmente porque não estáo disponíveis para o português europeu padrão dados de frequência que pudessem ser comparados com os que seráo apresentados neste trabalho. 
Harris e Halle (2005), não faz, só por si, prever. O artigo organiza-se em 5 secçóes. $\mathrm{Na}$ secção 2. faz-se uma apresentação panorâmica da colocação dos pronomes clíticos nos dialetos portugueses dos arquipélagos dos Açores e Madeira, como visualizável no CORDIAL-SIN, e identificam-se os dois tipos de dados atípicos que serão explorados nas secçôes seguintes. A secção 3 é dedicada à ênclise nos contextos em que tipicamente ocorre a próclise em frases finitas. Estes contextos permitirão observar tanto paralelismos como diferenças entre os dialetos açorianos e os dialetos madeirenses; mas também, quando o foco é o arquipélago da Madeira, diferenças entre a ilha da Madeira e a ilha de Porto Santo e, talvez, variação que não é só geográfica, mas que a pequena dimensão do corpus apenas permite apontar como hipótese. Nesta secção mostrar-se-á também que há contextos favorecedores da ênclise atípica, nomeadamente as oraçôes relativas e as frases que incluem certos advérbios (como até e também). A questáo que se coloca nestes casos é se será realmente atípica a colocação do clítico ou antes decorrente de especificidades da sintaxe de alguns tipos de relativas ou da mudança de certos advérbios de indutores categóricos de próclise para não categóricos (cf. Martins 2016). Nesta perspetiva, a frequência das colocaçóes atípicas poderá talvez ser menor do que salta à vista. A secção 4 ocupa-se da próclise atípica nos domínios não finitos (infinitivo, gerúndio e particípio passado). Embora o número de ocorrências seja baixo, os dados são percentualmente significativos e revela-se interessante a comparação com variedades não europeias do português. Se a próclise ao infinitivo simples, não introduzido por preposição, pode encontrar-se esporadicamente na produção de falantes cultos (cf. (3a-b) acima), a próclise ao gerúndio e ao particípio passado parece ser estranha ao português europeu não dialetal, tendo, no entanto, considerável expressão em variedades do português em África (além, claro, do português brasileiro). Na secção 5 apresentam-se os principais resultados deste estudo.

\section{Próclise, ênclise, reduplicação e interpolação nos dialetos açorianos e madeirenses}

O padráo dominante de colocação dos pronomes clíticos nos dialetos portugueses dos arquipélagos dos Açores e da Madeira não difere do que está descrito para o português europeu nas gramáticas e outras obras de referência (Duarte 2003; Martins 2013, 2016). Com as formas finitas do verbo, os pronomes são, em geral, enclíticos nas frases matriz afirmativas, como em (5), mas proclíticos nas oraçóes subordinadas e nas frases negativas, como em (6).

(5) O pai deu-lhe um saco de dinheiro e ele caminhou. PIC04

(6) Ando aqui para ver se me lembrava do príncipe Brilhante, mas não me alembra. PIC03 
Além disso, nas frases matriz afirmativas, a ênclise dá lugar à próclise nas interrogativas e exclamativas qu-, como ilustrado em (7a-b) e quando precedem o verbo quantificadores e certos advérbios, como se exemplifica em (8a-d) com os quantificadores muita, todos, ambas, alguém e em (9) com os advérbios até, também, só, já, ainda, sempre, lá. $\mathrm{O}$ efeito que estes itens têm na posição do pronome clítico relativamente ao verbo motiva a sua designação como proclisadores, termo que também se aplica à negação e palavras negativas e a todos os tipos de introdutores de orações subordinadas.

(7) a. Como se chama? Caranguejo estonado. CLC14

b. Que eu the fazia igual àquilo ou ainda melhor! GRC13

(8) a. ele muita vez se mete na boca com um pingo de café e pronto! PIC06

b. Todas elas se arrastam; adere aos muros de pedra - todas as heras, as variedades... MIG30

c. Ambas se fritam e ambas se cozem. CRV11

d. eu a falar nisso, alguém me disse que não, que já substituíam era pelos cobertores grossos CDR07

(9) a. Até eu lhe posso fazer vimes daqueles com estes... PIC01

b. Pois, também se usa. Esses que andam à pesca da lagosta utilizam aquilo. PIC31

c. Antigamente só se cozia massa sovada com rapa e com palha de tremoço. CDR30

d. Às vezes, acontece; já se aconteceu. PIC11

e. Eu ainda me lembro disto, mestre Balduíno PIC13

f. Em nossa casa sempre se chamuscou o porco foi com rameira. CDR10

g. amassamos, enrolamos o nosso bolo e tendemos e lá o cozemos. PIC06

Quando o hospedeiro do clítico é uma forma não finita do verbo, ou seja, o infinitivo ou o gerúndio, ocorre a ênclise na ausência de negação e preposições, mas a próclise torna-se possível ou obrigatória na presença destes itens (as preposiçóes são também elementos proclisadores, ainda que não categóricos nas orações com o infinitivo simples). Assim, em (10a-b), a oração infinitiva não preposicionada legitima a ênclise, enquanto a preposição introdutora da oração infinitiva (para, de) ou a negação (não) legitimam a próclise em (11a-c). Diferentes preposições podem afetar diferentemente a colocaçáo dos pronomes clíticos, destacando-se a preposiçáo $a$ por, em geral, as oraçóes infinitivas que introduz se comportarem, no aspeto relevante, como as infinitivas sem preposição.

(10) a. Aqui não há. Há pouco, muito pouco. Eu agora vê-lo! CLC06

b. Os meus pais náo podiam mesmo dar-me a escola. Náo podiam pagar. CLC12 
(11) a. Paguei a uma professora particular para the dar a escola. CLC11

b. A vinha é assim rasteira e a gente arranja umas estacas mais ou menos assim, para ficarem levantadas do chão, para a uva não se estragar no chão e o vento não a sacudir. PST01

c. E a minha mãe (...) gostava de lhe dar um calor no forno, por causa de ficar assim mais torrada, para moer melhor e ficar o pão mais gostoso. PST18

No padrão dominante de colocação dos pronomes clíticos, a cliticização ao particípio passado não é possível, ocorrendo sempre subida do clítico e cliticização ao verbo finito nas sequências verbais com particípio passado.

Definida em traços largos a colocação dos pronomes clíticos no português europeu, incluindo os seus dialetos, vamos agora focar a nossa atenção nas colocaçóes que se afastam deste quadro geral. A tabela 1 dá-nos uma primeira visão panorâmica das colocaçóes atípicas registadas no corpus CORDIAL-SIN para os dialetos açorianos e madeirenses. ${ }^{5}$

\begin{tabular}{|c|c|c|c|c|c|c|c|}
\hline & \multicolumn{3}{|c|}{ Verbo finito } & \multirow{2}{*}{\multicolumn{3}{|c|}{$\begin{array}{c}\text { Verbo não finito } \\
\text { Próclise } \\
\text { (atipicaltotal) }\end{array}$}} & \multirow{3}{*}{ Total } \\
\hline & \multirow{2}{*}{$\begin{array}{l}\text { Ênclise } \\
\text { (atipical } \\
\text { total) }\end{array}$} & \multirow{2}{*}{$\begin{array}{l}\text { Próclise } \\
\text { (atípical } \\
\text { total) }\end{array}$} & \multirow[t]{2}{*}{ Total } & & & & \\
\hline & & & & Infinitivo & Gerúndio & Part. Pass. & \\
\hline \multirow{2}{*}{ AÇORES } & $94 / 2292$ & $21 / 1338$ & $115 / 3630$ & $21 / 266$ & $4 / 4$ & 0 & $25 / 270$ \\
\hline & $4,1 \%$ & $1,6 \%$ & $3,2 \%$ & $7,9 \%$ & $100 \%$ & $\%$ & $9,3 \%$ \\
\hline \multirow{2}{*}{ MADEIRA } & $42 / 448$ & $4 / 154$ & $46 / 602$ & $7 / 29$ & $1 / 1$ & $1 / 1$ & $9 / 31$ \\
\hline & $9,4 \%$ & $2,6 \%$ & $7,6 \%$ & $25 \%$ & $100 \%$ & $100 \%$ & $29 \%$ \\
\hline \multirow{2}{*}{ Total } & $136 / 2740$ & $25 / 1492$ & $161 / 4232$ & $28 / 295$ & $5 / 5$ & $1 / 1$ & $34 / 301$ \\
\hline & $5 \%$ & $1,7 \%$ & $3,8 \%$ & $9,5 \%$ & $100 \%$ & $100 \%$ & $11,3 \%$ \\
\hline
\end{tabular}

Tabela 1. Açores e Madeira (geral) - ênclise e próclise atípicas face ao total de ocorrências de ênclise e próclise no CORDIAL-SIN, por domínio sintático relevante

Podemos observar que as colocaçóes atípicas se encontram tanto nos domínios finitos como não finitos. ${ }^{6}$ Nos primeiros, manifestam-se como ênclise atípica, em contextos sintáticos que são tipicamente indutores de próclise, e como próclise atípica, em frases matriz afirmativas sem proclisadores. Nos domínios não finitos, ocorre

5. Na tabela 1, a coluna Infinitivo integra o infinitivo simples e o infinitivo flexionado.

6. Não incluí na ênclise atípica estruturas com que e porque explicativos ou as locuçóes de maneira que, de forma que, pois nestas a ênclise ocorre comummente também na variedade padrão e, presumivelmente, em todos os dialetos do português europeu, podendo ser analisadas como estruturas paratáticas, ou seja, configuraçóes de coordenação e não de subordinação. Algumas ocorrências de que etiquetado como /WPRO no CORDIAL-SIN foram interpretadas como que explicativo. 
próclise atípica na ausência de negação e preposiçóes ou na presença da preposição $a$. Destaca-se, além disso, uma atestação de próclise ao particípio passado, que apesar de isolada pode ser significativa, como se discutirá na secção 4. Comparando os dados do arquipélago dos Açores com os do arquipélago da Madeira, vemos que a frequência das colocaçóes atípicas é mais alta na Madeira do que nos Açores, uma observação que será confirmada e reforçada pelos dados que discutiremos na secção 3. É ainda de notar que, nas frases com verbo finito, a ênclise atípica é globalmente mais expressiva do que a próclise atípica. Exemplifica-se de seguida: em (12), a ênclise atípica ao verbo finito (em exclamativa qu- (a), com os advérbios também, até, talvez (b)-(d), com o quantificador toda (e), em frases negativas (f-h), em subordinadas adverbiais (i)-(j), em relativas (l)-(m), em clivadas (n)-(o), em completiva (p)); em (13), a próclise atípica ao verbo finito; em (14), a próclise atípica ao infinitivo e ao gerúndio. Note-se em (12h) a variação entre ênclise e próclise nas duas frases negativas contíguas.

(12) a. O que esta senhora vai-se rir! CLH08

b. Também usa-se preto lá? TRC62

c. Aquilo até enxugavam-no e escolhiam-no. CLH05

d. Talvez estou-lhe a dizer depressa, não pode escrever tão depressa, não é? CRV04

e. Depois toda a gente calou-se. Meu pai é que estava certo. TRC42

f. Não havia plástico. Não. Nem sequer falava-se nisso. Nada, nada. STE12

g. O meu pai sempre foi lavrador e os meus irmãos foram todos lavradores, e eu nunca conheci-lhe mais que dez, doze vacas. MIG04

h. Se fosse muita quantidade, que a gente visse que era muita quantidade, não vinha-se, não se tinha hora de vir para a terra. CLC13

i. Todos os dias, quando eu vou-me à missa, ela fica aqui. MIG46

j. Ele o rapaz lembra-se: "Ah, se a gente formos-lhe à porta pedir água”... STE13

1. Mas há pessoas que salgam-nas. PIC29

$\mathrm{m}$. E era uma casa de uma família pobre, ali, de raparigas, que tinha-lhe morrido o pai CDR33

n. Não, mas o que eu quis-te fazer foi uma imitação do que vai ser o improviso. TRC34

o. E ainda antes dessa vem uma outra, essa é que a gente trata-lhe por a estrela. GRC08

p. Nunca fui, não é? Se ia, já sabia que ia-me assustar. PIC16

(13) a. "Homem, tu o viste no outro dia, porque é que queres tornar a ver"? PIC20

b. E eu me lembra um ano que meu pai - acho que como a minha máe não tinha dinheiro (...) PST19 
c. A gente a punha e tirava. MIG17

d. Sendo uma pipa grande, the chamam a pipa, estas chama-se é cartolas PST06

e. Depois de estarem os ovinhos mexidinhos, se deita a farinha, deita a levedurazinha e depois é que vai amassando. PIC05

f. Agora me explique isso. PIC09

g. Mas aqui se tratavam muito era bacorinhos. MIG10

h. Porque o estrume deitado agora na terra e a terra estando até Abril sem ser semeada, quando se semeia o milho, a água já derreteu aquilo tudo, já não está nada na terra, se pode dizer. CRV60

i. Não. Se aproveitava para os animais! GRC26

j. A gente aí já foi assim; se ajuntaram já foi antes de mim! STE08

1. Também uma mancheia de salsa; se pica uma mancheia de salsa. FLF65

(14) a. Ando. Andar, ando; mas me ajoelhar e a coisa, não. [INQ: Pois, pois.] Sempre me tratando. O Senhor Doutor já me quis operar dos joelhos mas eu não quis. PST10

b. Não posso então the explicar. PIC09

c. Era raro se lavrar mais de uma vez para semear o milho. CRV64

d. Com uma chucha, chegam a se criarem em casa. FLF66

e. Vamos mexendo aquilo dois, três dias, de manhã e à noite, vai sempre se mexendo. PIC07

Os dados em (13) que, note-se, incluem clíticos em posição inicial de frase (cf. (13i)-(13l)), não parecem diferir substancialmente da próclise que se regista em frases que expressam afirmação enfática (Martins 2013: 2268-2270). Em todos eles poderemos ver casos de ênfase assertiva (verum focus, como discutido em Höhle 1992; Lohnstein 2016; Gutzmann, Hartmann \& Matthewson 2020), em que o falante exprime um compromisso forte com a verdade da proposição (ou algum tipo de ênfase expressiva), denotando um juízo/comentário avaliativo. Estes dados não serão objeto de análise mais aprofundada no presente artigo. ${ }^{7}$

Vejamos agora como se distribuem as ocorrências da ênclise atípica por contexto sintático e no espaço geográfico. A tabela 2, relativa ao arquipélago dos Açores, mostra-nos que a ênclise atípica ocorre em todos os tipos de ambientes sintáticos tipicamente indutores de próclise (tanto as frases matriz afirmativas em que precedem o verbo itens proclisadores, como as frases negativas e as oraçóes subordinadas finitas), como a hipótese de metátese pós-sintática (Magro 2007, 2010) faria prever. Mostra-

7. As 21 ocorrências de próclise atípica nos Açores distribuem-se por todas as ilhas: Corvo 2, Flores 1, Faial 3, Pico 4, São Jorge 1, Graciosa 1, Terceira 3, São Miguel 3, Santa Maria 3. No arquipélago da Madeira, a próclise atípica regista-se apenas na ilha de Porto Santo, com 3 ocorrências na Camacha e 1 em Tanque. 
-nos também que a ênclise atípica se regista em todas as ilhas dos Açores. Embora em algumas ilhas o fenómeno pareça ser mais produtivo do que noutras (Pico, Terceira, Faial e Santa Maria apresentam, por ordem decrescente, o número mais elevado de ocorrências), as diferenças não parecem ser muito significativas. A última linha da tabela mostra-nos quais os advérbios que, sendo proclisadores categóricos no português europeu padrão (cf. Martins 2016: 407), não excluem a ênclise nos dialetos açorianos. Voltaremos a falar deles na secção 3.

\begin{tabular}{|c|c|c|c|c|c|c|c|c|c|}
\hline \multirow{2}{*}{$\begin{array}{l}\text { Arquipélago } \\
\text { dos Açores }\end{array}$} & \multicolumn{2}{|c|}{ Grupo Ocidental } & \multicolumn{5}{|c|}{ Grupo Central } & \multicolumn{2}{|c|}{ Grupo Oriental } \\
\hline & Corvo & Flores & Faial & Pico & $\begin{array}{l}\text { São } \\
\text { Jorge }\end{array}$ & Graciosa & Terceira & $\begin{array}{c}\text { São } \\
\text { Miguel }\end{array}$ & $\begin{array}{l}\text { Santa } \\
\text { Maria }\end{array}$ \\
\hline Advérbios* & 4 & 1 & 6 & 9 & 3 & 2 & 5 & 1 & 2 \\
\hline $\begin{array}{l}\text { Quantifica- } \\
\text { dores }\end{array}$ & & & & 1 & & & 1 & & \\
\hline Exclamativas & & & & & 1 & 1 & & & \\
\hline$Q U-/ S E$ & & & & & $q u-$ & se & & & \\
\hline Negação & & & & 4 & & 1 & 1 & 1 & 1 \\
\hline Relativas & 1 & 2 & 3 & 1 & 2 & 1 & 5 & 1 & 3 \\
\hline Clivadas & 1 & 1 & & & & 1 & 2 & & 1 \\
\hline Completivas & & & & 4 & & 2 & & & 1 \\
\hline Temporais & & & 2 & & & 1 & 1 & 2 & 1 \\
\hline Condicionais & 2 & & & 1 & & & & 1 & 2 \\
\hline $\begin{array}{l}\text { Outras } \\
\text { subordinadas }\end{array}$ & & & 1 & 3 & & & & & \\
\hline Total [94] & 8 & 4 & 12 & 23 & 6 & 9 & 15 & 6 & 11 \\
\hline *Advérbios & $\begin{array}{l}\text { também } 2 \\
\text { até } 1 \\
\text { talvez } 1\end{array}$ & também 1 & $\begin{array}{l}\text { tam- } \\
\text { bém } 2 \\
\text { até } 2 \\
\text { já } 2\end{array}$ & $\begin{array}{l}\text { também } \\
4 \\
\text { ainda } 1 \\
\text { lá3 } \\
\text { sempre } 1\end{array}$ & $\begin{array}{l}\text { também } \\
1 \\
\text { até } 2\end{array}$ & $\begin{array}{l}\text { até } 1 \\
j a ́ 1\end{array}$ & $\begin{array}{l}\text { também } 2 \\
\text { ainda } 2 \\
\text { lá } 1\end{array}$ & também 1 & $\begin{array}{l}\text { também } 1 \\
\text { ainda } 1\end{array}$ \\
\hline
\end{tabular}

Tabela 2. Açores (frases finitas) - distribuição contextual da ênclise atípica, por ilha

Relativamente ao arquipélago da Madeira, composto pelas ilhas da Madeira e de Porto Santo, dividirei cada um dos pontos do CORDIAL-SIN nas duas localidades em que foram obtidas as gravaçóes transcritas no corpus, obtendo assim a tabela 3. Esta subdivisão justifica-se porque se mostrará relevante para analisar a microvariação observada nos dialetos madeirenses, apesar da diminuta extensão das amostras correspondentes a Caniçal, na ilha da Madeira, e Tanque, na ilha de Porto Santo. ${ }^{8}$

8. Das 9.369 palavras de CLC, 7.438 pertencem a Câmara de Lobos e 1.931 ao Caniçal. Das 9.791 palavras de PST, 8.245 pertencem à Camacha e 1.546 a Tanque. 


\begin{tabular}{|c|c|c|c|c|}
\hline \multirow{2}{*}{$\begin{array}{l}\text { Arquipélago } \\
\text { da Madeira }\end{array}$} & \multicolumn{2}{|c|}{ Madeira } & \multicolumn{2}{|c|}{ Porto Santo } \\
\hline & Câmara de Lobos & Caniçal & Camacha & Tanque \\
\hline Advérbios* & 11 & & 2 & \\
\hline Negaçấo & 1 & & & \\
\hline Relativas & 10 & 3 & 1 & 3 \\
\hline $\begin{array}{l}\text { Clivadas/Interro- } \\
\text { gativas de é que }\end{array}$ & 3 & & & 1 \\
\hline Completivas & & 2 & & \\
\hline Temporais & 2 & 2 & & \\
\hline $\begin{array}{l}\text { Outras } \\
\text { subordinadas }\end{array}$ & 1 & & & \\
\hline Total [42] & 28 & 7 & 3 & 4 \\
\hline \multirow[t]{4}{*}{ *Advérbios } & também 7 & & & \\
\hline & até 2 & & até 2 & \\
\hline & ainda 1 & & & \\
\hline & já 1 & & & \\
\hline
\end{tabular}

Tabela 3. Madeira (frases finitas) - distribuição contextual da ênclise atípica, por localidade

$\mathrm{Na}$ tabela 3 continuamos a ver a ênclise atípica a ocorrer nos principais tipos de contextos sintáticos. Mas comparando-a com a tabela 2, surgem duas diferenças importantes. Por um lado, o número de ocorrências de ênclise atípica na ilha da Madeira é significativamente superior ao de qualquer das ilhas dos Açores, não sendo isso o efeito de uma maior extensão da amostra. ${ }^{9}$ Por outro lado, há um contraste muito claro entre a ilha da Madeira e a ilha de Porto Santo, onde as atestaçôes de ênclise atípica são muito pouco expressivas. Além disso, dentro da ilha de Porto Santo, a Camacha distingue-se de Tanque. A informante principal da Camacha apresenta apenas duas ocorrências de ênclise atípica, ambas com o advérbio até. É o seu marido que produz a oração relativa com ênclise. Em Tanque, apesar da pouca extensão da amostra, o moleiro produz três oraçóes relativas e uma clivada com ênclise. $\mathrm{O}$ reduzido número de dados não nos permite decidir se a microvariação que se desenha em Porto Santo é geográfica (Camacha vs. Tanque), idioletal ou, mais interessante, determinada pelo género (mulher vs. homens). Refira-se aliás que os dados da ilha da Madeira pertencem todos a pescadores, homens.

Nos domínios náo finitos, a próclise atípica distribui-se como nos mostram as tabelas 4 e 5 . Na tabela 4, relativa aos Açores, merece destaque o facto de a ilha com mais ênclise atípica em frases finitas ser também a que apresenta mais próclise atípica com as formas não finitas do verbo, i.e. a ilha do Pico, que juntamente com as Flores exibe próclise atípica com o infinitivo (simples e flexionado) e com o gerúndio. Não se trata neste caso de variação idioletal ou de género, pois contribuem para a amos-

9. Veja-se a nota 1 . 
tra vários informantes, homens e mulheres. Não se regista nenhuma ocorrência de próclise atípica (ao infinitivo/gerúndio) na ilha Terceira, mas não se pode daí deduzir a sua inexistência, dado que o número de atestaçóes se limita a 1 ou 2 exemplos em cinco das nove ilhas.

\begin{tabular}{lccccccccc}
\hline \multirow{2}{*}{$\begin{array}{l}\text { Arquipélago } \\
\text { dos Açores }\end{array}$} & \multicolumn{2}{c}{ Grupo Ocidental } & \multicolumn{4}{c}{ Grupo Central } & \multicolumn{2}{c}{ Grupo Oriental } \\
\cline { 2 - 10 } & Corvo & Flores & Faial & Pico & S. Jorge & Graciosa & Terceira & $\begin{array}{c}\text { Sáo } \\
\text { Miguel }\end{array}$ & $\begin{array}{c}\text { Santa } \\
\text { Maria }\end{array}$ \\
\hline Infinitivo & 2 & 4 & 1 & 7 & 2 & 3 & & & 2 \\
Gerúndio & & 1 & & 2 & & & & 1 & \\
Total [25] & 2 & 5 & 1 & 9 & 2 & 3 & 0 & 1 & 2 \\
\hline
\end{tabular}

Tabela 4. Açores (infinitivo e gerúndio) - distribuição da próclise atípica por ilha

No arquipélago da Madeira, destaca-se o facto de a localidade com menos ênclise atípica em frases finitas, i.e. a Camacha, ser a que tem mais próclise atípica com infinitivo e gerúndio. ${ }^{10}$ Mas é em Câmara de Lobos que se regista o único exemplo de próclise ao particípio passado (cf., abaixo, a nota 27 ).

\begin{tabular}{lcccc}
\hline \multirow{2}{*}{$\begin{array}{l}\text { Arquipélago } \\
\text { da Madeira }\end{array}$} & \multicolumn{2}{c}{ Madeira } & \multicolumn{2}{c}{ Porto Santo } \\
\cline { 2 - 5 } Infinitivo & Câmara de Lobos & Caniçal & Camacha & Tanque \\
Gerúndio & 1 & 1 & 4 & 1 \\
Particípio Passado & 1 & & 1 & \\
Total [9] & 2 & 1 & 5 & 1 \\
\hline
\end{tabular}

Tabela 5. Madeira (infinitivo, gerúndio e particípio passado) - distribuição da próclise atípica por ilha

O baixo número de ocorrências de cliticização ao infinitivo, tanto nos Açores como na Madeira, deve-se à alta frequência da subida do clítico. Os dados da próclise atípica nos domínios não finitos ganham outro significado quando comparados com as ocorrências de ênclise no mesmo contexto, como se verá na secção 4 .

Para concluir esta visão panorâmica, consideraremos os dados da interpolação e da reduplicação, que se exemplificam respetivamente em (15) e (16). Em (15) vemos interpolados entre o clítico e o verbo, separando-os, os pronomes a gente, eu (15a-b) e os advérbios já, cá (15c-d). Em (16) há dupla realização fonológica do mesmo clítico. A frase (16a) mostra a repetição do clítico à esquerda e à direita do verbo, enquanto (16b) exibe a repetição do clítico à esquerda e à direita do advérbio interpolado já.

10. É também a localidade com mais próclise atípica nas frases finitas (cf. nota 7). 
(15) a. Uê, é aquilo que se a gente enfia os fios para vir para o pente - para vir para o pente! FLF20

b. Se lhe eu disser PIC09

c. Como eu the já disse, vinham as ovelhas do baldio para baixo, para essas terras da cultura. CRV57

d. Volta atrás ter com as tuas famílias, e depois então se resolveres a virar para te cá vir... TRC43

(16) a. E meu homem trabalhou lá vinte e três anos e ele tinha sete reses, nem sequer the deu-lhe uma juntinha de gado GRC31

b. As tripas, sim, eu nunca me já me lembro de se limpar tripas na ribeira CDR18

$\mathrm{Na}$ análise de Magro $(2007,2010)$, ênclise atípica, interpolação e reduplicação são diferentes faces de um mesmo processo morfológico que se aplica opcionalmente na componente pós-sintática da gramática. Seguindo a teoria de Harris e Halle (2005), construída a partir da observação dos frequentes processos de reduplicação fonológica e morfológica nas línguas do mundo, Magro $(2007,2010)$ propóe que os diferentes padróes atípicos de ordem das palavras ilustrados em (12), (15) e (16) decorrem todos do processo de reduplicação, como formalizado por Harris e Halle (2005). As diferentes linearizaçóes resultantes são o efeito das diferentes possibilidades de apagamento parcial das cópias da sequência repetida. ${ }^{11}$ Apagamentos parciais desencontrados em cada uma das cópias produzem o efeito de metátese, que observamos na ênclise atípica e na interpolação, enquanto o apagamento parcial em apenas uma das cópias produz o efeito de repetição do clítico. A derivação dos três padróes relevantes é exemplificada em (17): (17a) corresponde à ênclise atípica, (17b) à interpolação, (17c) à reduplicação em torno do verbo, (17d) à reduplicação em torno de um item interpolável. Nas representaçôes em (17), os parêntesis retos delimitam a sequência a copiar (duplicando-a) e o(s) ângulo(s) indica $(m)$ que item será apagado em qual das cópias. $\mathrm{O}$ rasurado indica os itens apagados, apenas para clarificação.

(17) a. como eu [lhe $><$ disse $\rightarrow$ como eu the disse lhe disse $=$ como eu disse-lhe

b. como [eu $><$ lhe] disse $\rightarrow$ como eu the eu the disse $=$ como lhe eu disse

c. como eu $[$ lhe $<$ disse $\rightarrow$ como eu lhe disse lhe disse $=$ como eu lhe disse-lhe

d. como [eu $>$ lhe] disse $\rightarrow$ como eu lhe eu lhe disse $=$ como lhe eu the disse

11. Nas línguas do mundo ocorrem processos de reduplicação total quando há repetição integral de uma determinada sequência, seja fonológica seja de outro nível gramatical, e de reduplicação parcial quando há apagamento parcial de uma ou de ambas as cópias da sequência repetida. 
Ênclise atípica e interpolação são manifestações de metátese morfológica cujo ponto de partida é diferente: na ênclise atípica a sequência marcada para duplicação consiste no clítico mais a palavra morfológica à sua direita, ou seja, o verbo; na interpolação, a sequência marcada para duplicação contém o clítico e uma palavra morfológica à sua esquerda (não ou um dêitico). Qualquer dos tipos de sequência duplicada pode originar reduplicação, em lugar de metátese, quando o clítico não é apagado em nenhuma das cópias. A reduplicação pode, portanto, estar associada quer à ênclise atípica, como em (17c), quer à interpolação, como em (17d). A análise de Magro $(2007,2010)$ faz prever que os diferentes padróes de ordem de palavras exemplificados em (17) apresentem, nos dialetos que admitem o processo de reduplicaçáo parcial relevante, um mesmo cenário de dispersáo por diferentes ambientes sintáticos. Os dados dos dialetos açorianos confirmam esta previsão, como mostra a tabela $6 .{ }^{12}$

\begin{tabular}{lccc}
\hline & INTERPOLAÇão & REDUPLICAÇão & ÊNCLISE \\
\hline Advérbios & $\sqrt{ }$ & $\sqrt{ }$ & $\sqrt{ }$ \\
Negação & $\sqrt{ }$ & $\sqrt{ }$ & $\sqrt{ }$ \\
Relativas & $\sqrt{ }$ & $\sqrt{ }$ & $\sqrt{ }$ \\
Clivadas & & $\sqrt{ }$ & $\sqrt{ }$ \\
Completivas (finitas e infinitivas) & $\sqrt{ }$ & $\sqrt{ }$ & $\sqrt{ }$ \\
Subordinadas adverbiais & $\sqrt{ }$ & $\sqrt{ }$ & $\sqrt{ }$ \\
\hline
\end{tabular}

Tabela 6. Açores - a correlação interpolação-reduplicação-ênclise em contextos tipicamente proclíticos

12. Registam-se nos Açores 11 ocorrências de interpolação, 2 das quais com o verbo no infinitivo (Uma coisinha de terra para se ele suster ali ele de pé CRV55), 2 ocorrências de interpolaçáo com reduplicação (O que eu souber, mas eu, como eu lhe já lhe disse.... CLH11), e 11 ocorrências de reduplicaçáo associada à ênclise atípica (Depois deita-se as couves na panela com a água a ferver e ou póe manteiga ou toicinho, aquilo que se queira-se botar. STE20), 5 das quais em oraçôes infinitivas preposicionadas. Encontram-se ainda no corpus açoriano dois exemplos de reduplicação em configuraçóes de subida do clítico (vd. (i)-(ii) abaixo), que não sấo casos de duplicaçáo morfológica, mas talvez de dupla realização de cópias resultantes de movimento sintático (cf. Nunes 2004). Ocorre também uma triplicação, numa estrutura muito complexa (vd. (iii)). A reduplicação em contexto de subida do clítico encontra-se igualmente em dialetos do catalâo (Bonet 2002) e de outras línguas românicas (Paradis 2019).

(i) Mas o que me dava que fazer era ele cheirar uma bocada hoje em casa da Francisca e outro dia em casa do Filipino e outro dia em casa da tua tia Gabriela, no outro dia, e aquilo não the ter ele feito despertar-lhe o vício CRV49

(ii) As pessoas usavam pouca linguiça náo porque não $a$ gostassem de $a$ comer, porque precisavam do dinheirinho e era uma maneira de fazer o dinheiro. CDR11

(iii) Minha mãe tinha-lhe escrito aqui numa data que ela the tinha-lhe mandado tho fazer. STE28 
Os dialetos madeirenses divergem dos dialetos açorianos por, de acordo com os dados do CORDIAL-SIN, não admitirem a interpolação. Isso quer dizer que nos dialetos madeirenses só a sequência clítico-verbo admite reduplicação, o que exclui (17b) e (17d). Espera-se, no entanto, que a par de (17a), i.e. a ênclise atípica, possa ocorrer (17c), i.e. próclise e ênclise simultâneas do clítico duplicado. Este tipo de reduplicação atesta-se em Câmara de Lobos, como mostra (18).

(18) Não há peixe que se ponha-se ao sol sem salgar. CLC10

Trata-se de uma ocorrência única, o que parece apontar para uma baixa produtividade, na Madeira, da reduplicação parcial que não resulta em metátese. Contudo, esta ocorrência única aparece exatamente onde seria esperável, quer dizer, na localidade com alta frequência de ênclise atípica para a qual dispomos de uma amostra suficientemente extensa. Numa localidade como a Camacha, sobretudo se nos centrarmos na informante feminina, que quase não produz ênclise atípica (cf. secção 3), é natural que também não ocorra o tipo de reduplicação que se vê em (18).

No corpus madeirense encontram-se duas frases que nos mostram clíticos divididos (split clitics), um fenómeno raro, pois as sequências clíticas são, em geral, inseparáveis. A frase (19a), que também pertence a Câmara de Lobos, é facilmente derivável pelo mecanismo de reduplicação parcial, que se aplicará antes da formaçáo do grupo clítico (clitic cluster), como se mostra em (20). ${ }^{13}$ Já (19b), pertencente à localidade de Tanque, em Porto Santo, não pode ser derivado da mesma forma pois na posição pré-verbal o clítico imediatamente contíguo ao verbo seria lhe, não se (i.e. que se the chama, tal como: nunca se lhe tocava com as mâos PST14). Sendo este um exemplo isolado, e não havendo evidência que nos permita admitir a possibilidade de inversão da ordem dos clíticos na sequência se lhe, deixamos por explicar este caso de split clitics.

(19) a. Que ela quando se apanha-os, ele deita aquele forrado preto. CLC26 (Câmara de Lobos)

b. Depois houve um tipo que quis me comprar a pedra, aquele que the chama-se o patamal. PST24 (Tanque)

13. A sequência formada pelo clítico se mais um clítico acusativo de terceira pessoa tem uma distribuição geográfica limitada no território português, mas ocorre nos dialetos madeirenses:

(i) Em sendo para a latada, deixa-se-a crescer, para cima a altura que a gente quiser. PST01 (Camacha)

(ii) Tinha-se um burrinho, ia-se buscar e levar a farinha. Trazia-se-o em grão e levava-se em farinha. PST24 (Tanque)

No corpus CORDIAL-SIN atesta-se também nos Açores e nos dialetos meridionais. O exemplo (iii) pertence a Santo Espírito (Santa Maria, Açores):

(iii) Pode-se-a guardar na 'freeze' e comer daqui a dois ou três meses. (STE36). 
(20) quando se [os $><$ apanha] $\rightarrow$ quando se es apanha os apanha = quando se apanha-os

Antes de passarmos à secção seguinte importa esclarecer que a regra de reduplicação não se aplica nos contextos tipicamente enclíticos (o que originaria um outro tipo de próclise atípica), porque verbo e enclítico, diferentemente de proclítico e verbo, constituem uma unidade morfológica (cf. Magro 2007).

\section{Microvariação na distribuição da ênclise atípica: Açores, Madeira, Porto Santo}

Nesta secção observaremos mais de perto a ênclise atípica em frases finitas, começando por considerar a variação geolinguística. Enquanto na tabela 1 comparámos ênclise atípica com ênclise típica, calculando a percentagem de ocorrência da ênclise atípica relativamente ao número total de ocorrências da ênclise em frases finitas no corpus, compararemos agora ênclise atípica com próclise típica, nos contextos sintáticos relevantes. Veremos assim, para os contextos em que na variedade padráo ocorre sempre (ou quase sempre) a próclise, o número de ocorrências e a percentagem de ênclise atípica por arquipélago e ilha/localidade. Isto é o que nos mostram as tabelas 6 e 7, correspondentes, respetivamente, aos arquipélagos dos Açores e da Madeira. Comecemos por focar-nos na primeira.

\begin{tabular}{|c|c|c|c|c|c|c|c|c|c|}
\hline \multicolumn{2}{|c|}{ GRUPO OCIDENTAL } & \multicolumn{5}{|c|}{ GRUPO CENTRAL } & \multicolumn{2}{|c|}{ GRUPO ORIENTAL } & \multirow[b]{2}{*}{ Total } \\
\hline CORVO & FLORES & FAIAL & PICO & $\begin{array}{c}\text { SÃO } \\
\text { JORGE }\end{array}$ & GRACIOSA & TERCEIRA & $\begin{array}{c}\text { SÃO } \\
\text { MIGUEL }\end{array}$ & $\begin{array}{l}\text { SANTA } \\
\text { MARIA }\end{array}$ & \\
\hline $4,4 \%$ & $3,8 \%$ & $3,4 \%$ & $12,1 \%$ & $6,4 \%$ & $10,2 \%$ & $8,7 \%$ & $4,5 \%$ & $10,8 \%$ & $6,7 \%$ \\
\hline $8 / 181$ & $4 / 104$ & $12 / 348$ & $23 / 180$ & $6 / 93$ & $9 / 88$ & $15 / 172$ & $6 / 133$ & $11 / 102$ & $94 / 1401$ \\
\hline
\end{tabular}

Tabela 7. Açores (frases finitas) - percentagem de ênclise atípica, por ilha, no total dos contextos tipicamente indutores de próclise

A tabela 7 não traz grandes surpresas, embora dê maior precisão aos resultados da secção anterior. Assim, confirma-se que em todo o arquipélago dos Açores as colocaçóes atípicas são largamente minoritárias relativamente às colocaçóes típicas e que, além disso, não há diferenças muito acentuadas entre as nove ilhas no que diz respeito à frequência da ênclise atípica, que varia no corpus entre os 3,4\% do Faial e os $12,1 \%$ do Pico. Tal como já mostrava a tabela 2, o Pico aparece como a ilha com maior incidência da ênclise atípica. Mas ao contrário do que fazia supor a tabela 2, o Faial é uma das ilhas com menor frequência da ênclise atípica. A diferença entre os 
resultados das duas tabelas explica-se facilmente: Sendo o Faial a ilha que apresenta no corpus o maior número de ocorrências de clíticos, a grande distância de todas as outras ilhas, o número absoluto de ocorrências de ênclise atípica parece relativamente alto, ainda que percentualmente não o seja. As pequenas diferenças quantitativas visualizáveis na tabela 7 não permitem identificar subáreas dentro dos dialetos açorianos. Notarei apenas que as três ilhas mais ocidentais (Corvo, Flores e Faial) são as que apresentam os valores mais baixos de ênclise atípica, no que são acompanhadas do lado oriental pela ilha de São Miguel, a mais populosa do arquipélago dos Açores e sede do poder político.

\begin{tabular}{|c|c|c|c|c|}
\hline \multicolumn{2}{|c|}{ MADEIRA } & \multicolumn{2}{|c|}{ PORTO SANTO } & \multirow[b]{2}{*}{ TOTAL } \\
\hline $\begin{array}{c}\text { CÂMARA DE } \\
\text { LOBOS }\end{array}$ & CANIÇAL & САМАСНА & TANQUE & \\
\hline $36,4 \%$ & $43,75 \%$ & $3,5 \%$ & $28,6 \%$ & \\
\hline $28 / 77$ & $7 / 16$ & $3 / 85$ & $4 / 14$ & \\
\hline \multicolumn{2}{|c|}{$37,6 \%$} & \multicolumn{2}{|c|}{$7,1 \%$} & $21,9 \%$ \\
\hline \multicolumn{2}{|c|}{$35 / 93$} & \multicolumn{2}{|c|}{ 7/99 } & $42 / 192$ \\
\hline
\end{tabular}

Tabela 8: Madeira (frases finitas) - percentagem de ênclise atípica, por localidade e por ilha, no total dos contextos tipicamente indutores de próclise

Quando comparamos a tabela 7 com a tabela 8, confirmamos também observaçôes já feitas, mas que agora se apresentam com maior nitidez. Diferentemente do que acontece no arquipélago dos Açores, há variação dialetal muito clara no interior do arquipélago da Madeira. Por outro lado, é aqui, contrariamente aos Açores, que podemos encontrar percentagens muito altas de ênclise atípica, perto dos $40 \%$ na ilha da Madeira. O contraste entre a ilha da Madeira e a de Porto Santo é muito grande, situando-se a percentagem de ênclise atípica em Porto Santo dentro do intervalo identificado para os Açores. Como já comentado na secção 2, há ainda uma separação dentro da ilha de Porto Santo entre as localidades da Camacha e Tanque, com a última a parecer alinhar mais com as localidades da ilha da Madeira. Mas a pequena quantidade de dados com que estamos a trabalhar não nos permite ir para além das hipóteses já levantadas na secção $2 .{ }^{14}$

14. Deve ainda ser dito que há que ter cautela quanto à interpretação dos dados da ilha da Madeira. Câmara de Lobos e Caniçal são duas vilas piscatórias (pertencentes a concelhos distintos) e os entrevistados são pescadores. A variedade dialetal descrita neste artigo, a partir dos dados do CORDIAL-SIN, pode náo ser comum a toda a ilha da Madeira, uma vez alargada a cobertura geolinguística e sociolinguística. Numa comunicação apresentada em 24.05.2019 na universidade de Zurique (Transgressóes insulares: variação sintática da ilha da Madeira), Carlota de Benito Moreno e Yoselin Henriques reportaram, a partir de dados recolhidos na cidade do Funchal, uma tendência para a expansão da próclise nas frases finitas tipicamente enclíticas, o que diverge da evidência empírica oferecida pelo CORDIAL-SIN. 
A expressão muito forte da ênclise atípica na ilha da Madeira pode fazer-nos pensar que esteja aí em curso alguma mudança mais profunda do que, simplesmente, um aumento significativo da produtividade da aplicação da regra de reduplicação que deriva a ênclise atípica. Contudo, a observação de outros dados revela paralelismos de comportamento gramatical entre a Madeira e os Açores que me levam a manter a hipótese de que a ênclise atípica seja derivada de forma similar nas duas regióes. Considerada a variação geográfica, olhemos agora para a variação contextual, isto é, de que modo se distribui a ênclise atípica por contextos sintáticos.

A tabela 9 mostra-nos qual a frequência da ênclise atípica nos três grandes grupos de contextos sintáticos que tipicamente legitimam a próclise nas frases finitas: as frases negativas, qualquer que seja a expressão gramatical da negação; as oraçôes subordinadas e estruturas $q u$-; as frases raiz afirmativas em que precedem o verbo certos advérbios ou quantificadores. Os resultados mostram-nos que, ao contrário do que poderia esperar-se, a frequência da ênclise atípica varia bastante entre contextos sintáticos, tendo a sua expressão mais ténue nas frases matriz negativas e mais forte nas frases matriz afirmativas com advérbios ou quantificadores indutores de próclise. Comparando entre si os arquipélagos dos Açores e da Madeira, verificamos que apresentam resultados convergentes no que diz respeito às frases negativas, com percentagens de ocorrência de ênclise atípica quase iguais. Divergem depois, claramente, nos valores para os outros dois grupos de contextos sintáticos, mas, significativamente, a escala de frequência é exatamente a mesma: do valor mais baixo nas frases negativas para o mais alto nas frases com advérbios e quantificadores, ficando as estruturas subordinadas e $q u$ - numa posição intermédia. Isto leva-me a concluir que a ênclise atípica é o mesmo tipo de fenómeno nos dialetos açorianos e madeirenses, resultando as diferenças geolinguísticas reveladas nas tabelas 7 e 8 do grau produtividade da operação pós-sintática de reduplicação/metátese, nos termos de Magro (2007, 2010). Acrescem questôes de microvariação, como a inexistência de interpolação e a fraca presença da repetição do clítico no arquipélago da Madeira, o que indica uma preferência pela variante da regra de reduplicação que resulta em metátese, ou seja, ênclise atípica.

\begin{tabular}{lccc}
\cline { 2 - 4 } & AÇORES & MADEIRA & TOTAL \\
\hline \multirow{2}{*}{ negaçáo e palavras negativas } & $3 \%$ & $2,9 \%$ & $3 \%$ \\
& $8 / 263$ & $1 / 35$ & $9 / 298$ \\
subordinadas e estruturas $q \mathcal{u}-$ & $7,2 \%$ & $28,3 \%$ & $9,8 \%$ \\
& $51 / 707$ & $28 / 99$ & $79 / 806$ \\
advérbios e quantificadores & $13,6 \%$ & $30,2 \%$ & $15,6 \%$ \\
\multirow{2}{*}{ TOTAL } & $35 / 264$ & $13 / 43$ & $48 / 307$ \\
& $7,6 \%$ & $25,1 \%$ & $9,6 \%$ \\
& $94 / 1235$ & $42 / 177$ & $136 / 1412$ \\
\hline
\end{tabular}

Tabela 9. Açores e Madeira (frases finitas) - percentagem de ênclise atípica em três tipos de contexto sintático 
É, contudo, intrigante que uma regra pós-sintática seja sensível a diferenças de estrutura sintática como as que estão em causa nos dados da tabela 9. Nos termos da teoria de Harris e Halle (2005), essa sensibilidade sintática é inesperada. A hipótese que coloco e que irei explorar exemplificativamente (porque explorá-la cabalmente iria muito para além dos limites deste artigo) é que nas frases negativas a ênclise atípica seja exclusivamente o resultado do fenómeno pós-sintático de reduplicação/ metátese, mas que nos outros contextos possa ser também consequência de variação dialetal na sintaxe dos advérbios (ou de alguns advérbios) e de alguns tipos de oraçóes subordinadas. Se esta hipótese estiver no caminho certo, uma parte da atipicidade não está na colocação do clítico, stricto sensu, mas na configuração sintática que determina a sua colocação. Limitarei a análise aos advérbios e às oraçóes subordinadas, com atenção particular às relativas. ${ }^{15}$

A tabela 10 mostra-nos todos os advérbios proclisadores registados no corpus para os dialetos açorianos e indica-nos qual a percentagem de ênclise atípica nas frases em que precedem o verbo. Dos dados quantificados nesta tabela excluímos todas as frases em que além do advérbio relevante ocorre algum outro indutor de próclise, o que explica os números um pouco mais baixos relativamente à tabela 9. Destaquei a negrito na tabela os dados percentuais que passarei a comentar, relativos aos advérbios já, também e até, os quais estão suficientemente representados no corpus para que os dados percentuais sejam significativos. Com o advérbio já a percentagem de ênclise atípica $(3,4 \%)$ é muito semelhante à que se verifica nas frases negativas $(3 \%)$, mas com também e até está muito acima desse valor, passando para os $20 \%$ com também e $42,9 \%$ com até. Estes resultados são muito interessantes e penso irem ao encontro da hipótese que coloquei, como passarei a explicar.

15. Há poucas ocorrências de quantificadores no corpus. Nos Açores registam-se ocorrências únicas de alguém, ambas, muita, muito, pouco, qualquer, toda, todas, todos, tudo. Na Madeira, há duas ocorrências de tanto e uma de tudo. 


\begin{tabular}{|c|c|c|c|c|c|c|c|c|c|c|}
\hline \multirow{2}{*}{ ADVÉRBIOS } & \multicolumn{2}{|c|}{$\begin{array}{c}\text { GRUPO } \\
\text { OCIDENTAL }\end{array}$} & \multicolumn{5}{|c|}{ GRUPO CENTRAL } & \multicolumn{2}{|c|}{$\begin{array}{c}\text { GRUPO } \\
\text { ORIENTAL }\end{array}$} & \multirow{2}{*}{$\begin{array}{c}\% \\
\text { ÊNCLISE }\end{array}$} \\
\hline & CORVO & FLORES & FAIAL & PICO & $\begin{array}{c}\text { SÃO } \\
\text { JORGE }\end{array}$ & GRACIOSA & TERCEIRA & $\begin{array}{c}\text { SÁO } \\
\text { MIGUEL }\end{array}$ & $\begin{array}{l}\text { SANTA } \\
\text { MARIA }\end{array}$ & \\
\hline ainda & $0 / 4$ & $0 / 2$ & $0 / 9$ & $1 / 1$ & & $0 / 2$ & $2 / 3$ & $0 / 2$ & $1 / 3$ & $15,4 \%$ \\
\hline assim & & & & & $0 / 1$ & & & & & $0 \%$ \\
\hline até & $1 / 2$ & $0 / 1$ & $2 / 6$ & $0 / 1$ & $2 / 2$ & $1 / 1$ & $0 / 1$ & & & $42,9 \%$ \\
\hline bem & $0 / 1$ & & & $0 / 1$ & & & & & & $0 \%$ \\
\hline dali & & & & $0 / 1$ & & & & & & $0 \%$ \\
\hline$j a ́$ & $0 / 12$ & $0 / 11$ & $2 / 21$ & $0 / 8$ & $0 / 5$ & $1 / 4$ & $0 / 14$ & $0 / 10$ & $0 / 3$ & $3,4 \%$ \\
\hline já cá & & & & $0 / 1$ & & & & & & $0 \%$ \\
\hline lá & $0 / 3$ & $0 / 2$ & $0 / 3$ & $3 / 11$ & & & $1 / 1$ & & $0 / 1$ & $19 \%$ \\
\hline mal & $0 / 1$ & & & & & & & & & $0 \%$ \\
\hline melhor & & & & & $0 / 1$ & & & & & $0 \%$ \\
\hline quase & & & & & $0 / 1$ & & & & & $0 \%$ \\
\hline sempre & & $0 / 1$ & $0 / 5$ & $1 / 1$ & $0 / 2$ & $0 / 1$ & & $0 / 2$ & & $8,3 \%$ \\
\hline só & $0 / 1$ & $0 / 1$ & $0 / 5$ & & $0 / 3$ & & & & $0 / 1$ & $0 \%$ \\
\hline talvez & $1 / 2$ & & & & & & $0 / 1$ & & & $33,3 \%$ \\
\hline talvez ainda & & & & & & & $0 / 1$ & & & $0 \%$ \\
\hline também & $2 / 7$ & $1 / 7$ & $2 / 25$ & $4 / 8$ & $1 / 3$ & & $2 / 7$ & $1 / 3$ & $1 / 7$ & $20,9 \%$ \\
\hline também já & & & $0 / 1$ & $0 / 2$ & & & & & & $0 \%$ \\
\hline TOTAL & $4 / 33$ & $1 / 25$ & $6 / 75$ & $9 / 35$ & $3 / 18$ & $2 / 9$ & $5 / 28$ & $1 / 17$ & $2 / 15$ & $33 / 255$ \\
\hline & $12,1 \%$ & $4 \%$ & $8 \%$ & $25,7 \%$ & $16,7 \%$ & $22,2 \%$ & $17,9 \%$ & $5,9 \%$ & $13,3 \%$ & $12,9 \%$ \\
\hline
\end{tabular}

Tabela 10. Açores (frases finitas) - percentagem de ênclise atípica com advérbios proclisadores, por advérbio

Os advérbios proclisadores, no seu conjunto, não correspondem a nenhuma das classes em que é habitual dividir os advérbios, seja qual for a tipologia que se adote. Além disso, tendo como referência a variedade padrão, alguns são proclisadores categóricos enquanto outros não o são. $\mathrm{O}$ que determina a separaçáo entre uns e outros são diferenças de comportamento sintático, que normalmente se associam a diferenças semânticas ou discursivas, que podem ser muito subtis. Advérbios que, na estrutura funcional da frase, se associem às posiçóes sintáticas que expressam polaridade ou foco induzem, nessas posiçôes, próclise. Se os mesmos advérbios também puderem associar-se a posiçôes de tópico ou posiçôes mais periféricas, serão, nessas posiçóes, irrelevantes no que diz respeito à colocação do clítico. Então, advérbios que possam facilmente ser focalizados (foco contrastivo) ou topicalizados, como por exemplos os advérbios locativos, serão proclisadores não categóricos, ocorrendo ora com próclise ora com ênclise, com as consequentes diferenças interpretativas (decorrentes de o advérbio ser um tópico 
ou antes um foco contrastivo). Pelo contrário, advérbios que, podendo associar-se às posiçóes sintáticas que expressam polaridade ou foco, não possam ser topicalizados nem ocupar posiçôes mais altas na periferia esquerda da frase serão proclisadores categóricos (para uma discussão detalhada deste assunto, veja-se Martins 2013).

Formando os advérbios proclisadores um grupo heterogéneo, cada um tem características gramaticais e discursivas próprias e é esperável que possam manifestar, independentemente, variação dialetal. No CORDIAL-SIN os advérbios até e também nem sempre são marcadores de foco inclusivo, podendo apresentar-se despojados, em menor ou maior grau, do valor de inclusão num conjunto identificado ou implícito no contexto discursivo. Para lá do aspeto interpretativo, há indicadores sintáticos que mostram que funcionam como marcadores discursivos, ocupando posiçóes muito periféricas na estrutura da frase. A corroborar esta descrição, a frase (21) mostra-nos o advérbio até a ocorrer à esquerda de um constituinte topicalizado (com o qual não forma uma unidade sintática nem entoacional, não tendo valor inclusivo), as frases (22) e (23) mostram-nos os advérbios até e também posicionados à esquerda do expletivo ele, um elemento muito alto na periferia esquerda da frase (Carrilho 2005) e que não interfere na colocação dos clíticos. ${ }^{16} \mathrm{Na}$ Graciosa, o advérbio até coocorre frequentemente com por acaso, como em (24) - note-se a ênclise em (24a) -, o que é indicador da sua proximidade funcional com este marcador discursivo (ambos sinalizam um desvio do tópico central da conversa para introduzir uma informação/ comentário que, parecendo secundária, tem relevância comunicativa ou afetiva para o falante). O advérbio também ocorre, por vezes, repetido, como se pode ver em (25) e o mesmo padrão se atesta, ainda que mais raramente, com até, como se vê em (26). Esta possibilidade de reiteração parece sinalizar as diferentes posiçôes que estes advérbios podem ocupar na estrutura da frase. Nos exemplos que se seguem, a pontuação é a que se encontra no CORDIAL-SIN - lembre-se que se trata de transcriçóes de produçóes orais e que as opçôes de pontuação são, em parte, subjetivas.

(21) O Hortão Fundo. [INQ: Hortão Fundo era o sítio?] Lá para diante. Lá no cabo lá da freguesia. Até a casa, ainda está lá uma nesguinha. CLH14

16. Também pode ocorrer igualmente imediatamente depois do expletivo ele, como em (i), entre um tópico pendente e o demonstrativo isto com valor expletivo, como em (ii), estar associado a um tópico pendente, como em (iii), ou preceder um constituinte topicalizado, como em (iv).

(i) A gente temos uma carta escrita [...] a dizer como é porque ele também a gente não aguentam tudo de cabeça. MIG55

(ii) Mas os remadores, também, isto vai-se acabando. TRC12

(iii) E eu também, era um bocado de trabalho para eu fazer, que eu não fazia não era um nem dois. GRC26

(iv) Era uma senhora que tinha marido, mas também, no exame, não gostava muito dele, talvez. STE14 
(22) Até, por acaso, ele a gente, às vezes, estamos no mar de noite e a gente diz aí... GRC08

(23) a. Também ele quem quer póe entrecosto, assim estas carnes mais inferiores, bocados de toucinho. CRV01

b. E na quinta-feira, também, ele já há sermão de lava-pés. STE19

(24) a. Até por acaso a gente trata-lhe a 'pojagem'. GRC06

b. A toninha costumamos trancar. [INQ: E come-se?] Alguém come. Eu até por acaso nunca comi. Agora no Pico, eles comem aquilo que é... GRC03

c. Isso até, por acaso, agora já é muito raro aparecer uma viola. GRC10

d. A gente até, por acaso, quando faz angélica, eu deixo sempre ficar o barril da angélica dentro duma dorna. Se arrebentar fica aproveitada. GRC21

(25) a. eu também, hoje, eu também como oficial também, às vezes, também ajudo na brincadeira.PIC16

b. Também, ainda hoje, também dei uma passagem numa parte que é a Bananeiras. CDR02

(26) Porque até a gente até por o São João fazíamos as fogueiras, íamos lá queimar e só ficava aquele piquinho. CLH18

Uma análise formal da sintaxe destes advérbios está fora dos objetivos do presente trabalho. Mas a conclusão que me importa retirar dos dados apresentados acima é que nos dialetos açorianos, diferentemente da variedade padrão, os advérbios até e também são proclisadores não categóricos, porque a sua sintaxe (e, portanto, também a interface sintaxe-discurso) é diferente da do português europeu padrão. Uma parte dos dados da ênclise atípica com estes advérbios será, pois, resultado da sua especificidade sintática (e semântico-discursiva) nos dialetos açorianos e madeirenses. Continuará a haver espaço para que outra parte decorra da aplicação da regra pós-sintática de reduplicação, como demonstra, aliás, a possibilidade de repetição do clítico em frases com também, como se vê em (27).

\section{(27) Também se faz-se chás. MIG28}

Outros advérbios mostram igualmente a possibilidade de posicionamentos periféricos, à esquerda, estranhos à variedade padrão, como se exemplifica com sempre, em (28). Por outro lado, a repetição do clítico como sinalizador da aplicação da regra pós-sintática de reduplicação atesta-se igualmente com já - veja-se (29).

(28) Sempre ao princípio assustam-se uma coisita, mas depois habituam-se àquilo, começam-se a habituar. PIC16

(29) Agora já a gente se deixou-se disso. GRC29 
Para concluir esta breve incursão no universo dos advérbios proclisadores, deixo a tabela 11, com os dados do arquipélago da Madeira, embora os considere pouco relevantes. Além de o total de ocorrências dos advérbios que nos interessam ser baixo, ocorrem maioritariamente em Câmara de Lobos os advérbios também e até (9/11), o que contribui certamente para os mais de $80 \%$ de ênclise atípica nesta localidade. Mais relevante é o facto de as duas únicas ocorrências de ênclise na Camacha acontecerem com o advérbio até, que tem nesta localidade características semelhantes às descritas para os dialetos açorianos, não sendo, portanto, um proclisador categórico. Sendo assim, a informante feminina da Camacha (cf. secçáo 2) apresenta um sistema de colocação dos clíticos a que parece ser estranha a regra pós-sintática de reduplicação. ${ }^{17}$

\begin{tabular}{|c|c|c|c|c|}
\hline \multirow{2}{*}{ ADVÉRBIOS } & \multicolumn{2}{|c|}{ MADEIRA } & \multicolumn{2}{|c|}{ PORTO SANTO } \\
\hline & CÂMARA DE LOBOS & CANIÇAL & САMACHA & TANQUE \\
\hline ainda & $1 / 2$ & & $0 / 2$ & \\
\hline assim & & & $0 / 1$ & \\
\hline até & $2 / 2$ & & $2 / 3$ & \\
\hline$j a ́$ & $1 / 1$ & & $0 / 20$ & \\
\hline só & & $0 / 1$ & & \\
\hline também & $7 / 7$ & & $0 / 1$ & \\
\hline TOTAL & $\begin{array}{l}11 / \\
84\end{array}$ & & & \\
\hline
\end{tabular}

Tabela 11. Madeira (frases finitas) - percentagem de ênclise atípica com advérbios proclisadores, por advérbio

Passando agora a observar a colocação dos pronomes clíticos nas orações subordinadas, veja-se a tabela 12, que compara a frequência da ênclise atípica em três tipos de subordinadas: as clivadas de é que, incluindo as interrogativas de é que e as relativas clivadas (Cardoso e Alexandre 2013); as subordinadas temporais com quando e as relativas com que. ${ }^{18}$ Estas três configuraçóes de subordinação são as que apresentam no corpus um maior número de ocorrências de ênclise atípica, com maior dispersáo

17. Numa das frases, até seria compatível com a presença de por acaso e na outra há uma reformulação, não sendo totalmente claro se a reformulação mantém ou abandona o advérbio até.

(i) Dava chuva, graças a Deus, punha terra a descampar, metia umas sementes aqui, outras acolá e dava abóbora. Até lembra-me um ano de meu pai ter cabaças. Umas cabacinhas de limpar o comer por dentro e depois fazer uma vasilhinha da água. PST19 (Camacha, mulher)

(ii) Então não dava centeio?! Acolá, aquela parte de areia que dava centeio - que eu tinha um tio - que dava centeio, até fa- serravam-lhe a espiga e do resto, faziam esteiras e faziam barracas, na rua, minha senhora. PST16 (Camacha, mulher)

18. Nesta tabela, tal como nas tabelas 10 e 11, quantificam-se apenas as frases em que não ocorrem outros indutores de próclise. 
geográfica (vejam-se, acima, as tabelas 1 e 2). Os números da tabela 12 mostram-nos de novo uma escala de frequência da ênclise atípica dependente do contexto sintático, e que se repete nos dois arquipélagos. De facto, embora os Açores e a Madeira se diferenciem bastante quanto aos números absolutos, com uma média de ocorrências de 5,8\% nos Açores face aos 33,8\% da Madeira, a escala de frequência das ocorrências por contexto sintático é idêntica: as clivadas de é que apresentam o valor mais baixo e as relativas de que o valor mais alto, ficando as subordinadas com quando num patamar intermédio. Acresce que as relativas constituem o único tipo de oração subordinada em que se atesta a ênclise atípica em todas as ilhas/localidades dos dois arquipélagos (cf. tabelas 1 e 2). Focarei a discussão nas relativas, consciente de que muito ficará ainda por aprofundar e explicar.

Clivadas de é que

Subordinadas temporais com quando

Relativas com que

TOTAL

\begin{tabular}{ccc}
\hline AÇORES & MADEIRA & TOTAL \\
\hline $2,6 \%$ & $18,2 \%$ & $4,5 \%$ \\
$4 / 154$ & $4 / 22$ & $8 / 176$ \\
$5,8 \%$ & $28,6 \%$ & $9 \%$ \\
$5 / 86$ & $4 / 14$ & $9 / 100$ \\
$8,5 \%$ & $48,4 \%$ & $14 \%$ \\
$16 / 189$ & $15 / 31$ & $31 / 220$ \\
$5,8 \%$ & $33,8 \%$ & $9,7 \%$ \\
$25 / 429$ & $23 / 68$ & $48 / 497$ \\
\hline
\end{tabular}

Tabela 12. Açores e Madeira (frases finitas) - percentagem de ênclise atípica em três tipos de subordinadas

No corpus CORDIAL-SIN, em geral, e em particular nas localidades dos Açores e Madeira, ocorrem frequentemente relativas cortadoras e relativas resuntivas. Comum aos dois tipos de oraçôes relativas é a ausência antes do que relativo da preposição que nas relativas a que chamarei preposicionadas marca a sua função gramatical. Os dois tipos de relativas náo preposicionadas diferenciam-se por nas resuntivas, ao contrário das cortadoras, a ausência da preposição ter como contraponto a presença, no interior da relativa, de um pronome pessoal (ou de um locativo) cujo caso corresponde à função gramatical do pronome relativo. Nem sempre é possível distinguir as estruturas não preposicionadas das estruturas tipicamente preposicionadas. Nas relativas de objeto direto e de sujeito, as cortadoras são superficialmente idênticas às preposicionadas, já que estas funçôes gramaticais não são marcadas por preposiçôes. As resuntivas podem ser indistintas das cortadoras nas relativas de sujeito, por o português ser uma língua de sujeito nulo. ${ }^{19}$ As relativas com ênclise atípica atestadas

19. Há na totalidade do corpus estudado 26 ocorrências de relativas com uma preposição a preceder o que relativo, todas nos Açores: 15 ocorrências com a preposição em, $10 \mathrm{com}$ a preposiçáo com e apenas uma com a preposição $a$, numa relativa livre. No arquipélago da Madeira, só se encontra que precedido 
nos dialetos açorianos e madeirenses são resuntivas, como exemplificado em (30), cortadoras, como exemplificado, em (31), ou frases ambíguas entre diferentes tipos de estruturas. ${ }^{20}$ Não há ocorrências de ênclise atípica em relativas com preposição a anteceder o que relativo. ${ }^{21}$ As relativas resuntivas, como mostram as frases (30g-h) não se restringem às relativas de que.

(30) a. Para mim, eu sinto-a muito, é uma tradição que eu sinto-a [...]. TRC06

b. Era um açougue que a gente queria-se mexer lá dentro e não podíamos. TRC55

c. E o tal fulano que ele devia-lhe dinheiro... TRC61

d. Ó, uma erva que cheira mui mal, Amélio, que a gente pega-lhe nas mãos e fica as mãos cheirando mal? FLF02

e. Já tem vindo aqui alguns que eu tiro-lhe uma talhada, desta forma, para ficar mais estreitos. GRC11

f. Aqui na Fajã dos Vimes, tem um lugar que chamam-lhe o rio, mas não é rio como há no continente nem nada disso. CLH29

g. Este é o que chamam-lhe... Em Benguela chama-se o alcatraz. CLC06

h. Ele o homem maluco, no meu entender, sábado à noite arruma o arado e foi passear para onde chamam-lhe o Tanque. CRV46

(31) a. [INQ: O que é a petinga?] Olhe, é um peixinho que a lula agarra-se. CLC18

b. Mas em França há desse que a gente chama-se dourado, mas isso esse aqui chama-se choupas. CLC21

de preposição em algumas, poucas, interrogativas qu- e comparativas.

20. Parece haver uma separação entre a Madeira, com preferência pelas relativas cortadoras, e os Açores, com preferência pelas relativas resuntivas. Mas há relativas cortadoras com próclise nos Açores (o cesto de carga era um cesto que se carreava o esterco para as terras.. CDR41; Eu no tempo que eu me casei ganhava-se era a quatro escudos. GRC31; A tesoura que a gente se tosquiavam as ovelhas! MIG58). Por outro lado, é resuntiva a relativa com clíticos divididos registada em Tanque e referida na secção 2 (Depois houve um tipo que quis me comprar a pedra, aquele que lhe chama-se o patamal. PST24), assim como a relativa em $(30 \mathrm{~g})$. Nas frases (31b) e (31f), acima, o clítico é o se nominativo das construçôes de duplo sujeito (Martins 2009).

21. Descontada uma relativa livre com a preposição com e próclise, no Corvo, há apenas quatro relativas com que precedido de preposição que contêm clíticos. Pertencem aos Açores (Faial e Terceira) e todas exibem próclise:

(i) E então temos todos os utensílios com que se trabalhava CDR07

(ii) Ia-se buscar muita madeira de cedro à rocha da caldeira, para fazer os cepos aquilo com que se fazia as galochas para calçar. CDR25

(iii) Levo até aos domingos em que se começa as funçôes. TRC20

(iv) $\mathrm{E}$ eu, tenho vinte e nove anos e só assisti a uma cantoria em que um indivíduo se calou. TRC36 
c. Depois ia-se na direcção. Estava ocasióes que dava-se com elas; e estava ocasiốes que não se dava. E quando se dava com elas, começava-se a balear. CLC28

d. Tinha uma argolazinha que amarrava-se um cordel. CLC31

e. Deita uma vara grande - tendo humidade e adubo. Deitou a vara que começa-se a fazer uma latada. PST01

f. Depois, em baixo, tinha uma agulha - a gente chamava-se a agulha que ia abaixo e tinha-se assim um pau atravessado, que a gente chamava-se o pau da agulha. PST23

Face aos dados apresentados, tem cabimento a hipótese de que a ênclise atípica nas relativas decorra não de um mas de dois fenómenos com expressão nos dialetos portugueses, que, somados, fazem das relativas um contexto sintático especialmente propiciador da ênclise atípica. Ou seja, a par da ênclise decorrente da aplicação da regra pós-sintática de reduplicação/metátese, haverá ênclise tornada possível por especificidades da sintaxe dialetal das oraçóes relativas resuntivas e cortadoras, que, presumivelmente, as aproximará de estruturas paratáticas (talvez na fronteira entre hipotaxe e parataxe, como as explicativas com que, pois, porque). A corroborar esta hipótese está o facto de no galego as relativas resuntivas (e possivelmente também as cortadoras) admitirem a ênclise. Álvarez e Xove (2002: 566), na Gramática da Lingua Galega, dizem-nos que "se pode producir énclise en oracións introducidas polo relativo que sem a preposición requirida pola función que desempeña na súa oración”, e dão como exemplo a colocação variável do clítico na relativa resuntiva em (32a-b), ainda que a descrição do tipo relevante de relativas cubra também as cortadoras. $\mathrm{Na}$ versáo preposicionada da mesma relativa apenas a próclise se regista no galego, como mostra (31c). ${ }^{22}$

(32) a. Había un home que aquel ano libráranlle un fillo da mili.

b. Había un home que aquel ano lle libraran un fillo da mili.

c. Había un home ó que aquel ano lle libraran un fillo da mili. (Galego. Álvarez \& Xove 2002: 566)

O mesmo tipo de variação entre a colocação proclítica e enclítica em relativas resuntivas pode ser ilustrada, nos dialetos açorianos, pela sequência textual em (33) a comparar com (32). Vemos em (33), bem perto entre si e diferenciando-se apenas na colocação do clítico, uma relativa resuntiva com ênclise seguida de outra com próclise. $\mathrm{O}$ exemplo pertence à ilha do Faial, onde as poucas ocorrências de relativas

22. Agradeço a Rosario Álvarez (comunicação pessoal) a confirmação de que, efetivamente, a ênclise pode ocorrer no galego também nas relativas cortadoras e não só nas resuntivas. Quanto à relativa em (32c), com que precedido de preposiçáo, a presença do pronome lle no interior da relativa é opcional. 
com que precedido de preposição apresentam invariavelmente o clítico em próclise (cf. nota 19). ${ }^{23}$

(33) E era uma casa de uma família pobre, ali, de raparigas, que tinha-lhe morrido o pai. E eram ali outras raparigas também que lhe tinha morrido o pai, as Jeremias. Eram estas as pessoas que todas as semanas passavam a pedir a sua brindeirinha de pão de milho. CDR32

Para completar a informação desta secção, cabe notar que, sem dúvida, a regra de reduplicação/metátese está na origem de parte dos casos de ênclise atípica nas relativas pois é possível atestar, nos dialetos açorianos e madeirenses, a duplicaçáo do clítico em oraçóes relativas, como se vê em (35). Note-se que (35b) é uma relativa cortadora, registada nos Açores onde, ao contrário da Madeira, as cortadoras apresentam, em geral, próclise, diferentemente das resuntivas. ${ }^{24}$

(35) a. Não há peixe que se ponha-se ao sol sem salgar. CLC10

b. Minha mãe tinha-lhe escrito aqui num a data que ela lhe tinha-lhe mandado lho fazer. STE28

c. Depois deita-se as couves na panela com a água a ferver e ou póe manteiga ou toicinho, aquilo que se queira-se botar. STE20

d. E depois passaram a deixar as sêmeas junto com o rolão, e faziam o bolo que se chamava-se o bolo inchado só com o rolão e com as sêmeas. CDR26

\section{Próclise atípica: infinitivo, gerúndio e particípio passado}

Os dados da tabela 13 mostram-nos a percentagem de próclise atípica em diferentes domínios não finitos, comparativamente às ocorrências de ênclise nesses mesmos domínios. Embora os dados não sejam abundantes, julgo-os significativos, quer percentualmente quer qualitativamente. ${ }^{25}$ Nesta tabela, o gerúndio dos complexos

23. A relativa cortadora em (34) contrasta com as frases de (31) na colocação do clítico (próclise em (34) vs. ênclise em (31)), pertencendo todas as frases aos dialetos madeirenses. Importa notar, contudo, que a frase (34) foi produzida pela informante feminina da Camacha, a qual tem sempre próclise em relativas.

(34) Mesmo que tenha um sítio, fiquei num lugar que ninguém me vê. PST19

24. Também se atesta a interpolação em relativas cortadoras:

(i) Ah, havia muitas, em tempo! Mas deixaram de usar. Antigamente, no tempo que me eu criei, que eu ainda me lembra de não haver nada disto fora. GRC13

25. A escassez de dados nos dialetos madeirenses deve-se à baixa frequência do infinitivo flexionado e à acentuada preferência pela subida do clítico nos contextos que a permitem. 
verbais com ir e estar está separado do gerúndio das oraçôes gerundivas porque há, nos dialetos açorianos, uma clara diferença entre os dois tipos de configuração sintática relativamente à colocação do clítico, com a próclise atípica a ocorrer apenas nos complexos verbais. Ao contrário do que observámos relativamente à ênclise atípica, Porto Santo aparece-nos agora como a área onde a colocação atípica do clítico tem maior expressão (embora o baixo número de ocorrências aconselhe a relativização do valor percentual de $100 \%$ ). Além disso, quatro das seis ocorrências de próclise atípica em Porto Santo pertencem à informante feminina da Camacha, que apresenta nas frases finitas, por oposição às não finitas, um padrão de colocação dos clíticos com raras manifestações de colocações atípicas. Isto indica-nos que não há correlação entre ênclise atípica nas frases finitas e próclise atípica com infinitivo e gerúndio, ainda que nos Açores seja a ilha do Pico que mostra os valores mais altos de ambas as colocaçôes atípicas (cf. acima as tabelas 2 e 4). Globalmente, apesar do menor número de ocorrências no corpus, a próclise atípica com infinitivo/gerúndio tem uma expressão percentual bastante mais elevada (cerca de 20\%) do que a ênclise atípica nas frases finitas (cerca de 9\%). ${ }^{26}$

\begin{tabular}{|c|c|c|c|c|c|c|}
\hline & & & & & & \\
\hline & INFINITIVO & A-INFINITIVO & $\begin{array}{c}I R / E S T A R \\
\text { GERÚNDIO }\end{array}$ & GERÚNDIO & $\begin{array}{l}\text { PARTICÍPIO } \\
\text { PASSADO }\end{array}$ & TOTAL \\
\hline \multirow{2}{*}{ Açores } & $12,5 \%$ & $22,6 \%$ & $57,1 \%$ & \multirow{2}{*}{$0 / 6$} & & $16 \%$ \\
\hline & $14 / 112$ & $7 / 31$ & $4 / 7$ & & & $25 / 156$ \\
\hline \multirow{2}{*}{ Madeira } & $33,3 \%$ & $100 \%$ & & \multirow{2}{*}{$0 / 1$} & $100 \%$ & $50 \%$ \\
\hline & $1 / 3$ & $1 / 1$ & & & $1 / 1$ & $3 / 6$ \\
\hline \multirow{2}{*}{ Porto Santo } & $100 \%$ & & & $100 \%$ & & $100 \%$ \\
\hline & $5 / 5$ & & & $1 / 1$ & & $6 / 6$ \\
\hline \multirow{2}{*}{ Total } & $16,7 \%$ & $25 \%$ & $57,1 \%$ & $12,5 \%$ & $100 \%$ & $20,2 \%$ \\
\hline & $20 / 120$ & $8 / 32$ & $4 / 7$ & $1 / 8$ & $1 / 1$ & $34 / 168$ \\
\hline
\end{tabular}

Tabela 13. Açores e Madeira (infinitivo, gerúndio e particípio passado) - percentagem de próclise atípica

26. Uma comparação por subáreas geográficas produz o mesmo resultado: no arquipélago dos Açores, 6,7\% de ênclise atípica comparam com 16\% de próclise atípica, na ilha da Madeira 37,6\% de ênclise atípica comparam com $50 \%$ de próclise atípica; na ilha de Porto Santo, $7,1 \%$ de ênclise atípica comparam com $100 \%$ de próclise atípica, sendo a região em que a diferença é mais notória.

Bazenga (2019) num artigo dedicado a "aspetos da sintaxe do português popular falado no Funchal”, ainda que não se ocupe da colocação dos pronomes clíticos, dá-nos as duas frases seguintes com próclise ao infinitivo. $\mathrm{Na}$ frase (i), o clítico do primeiro membro da estrutura coordenada está provavelmente cliticizado ao infinitivo e não ao verbo finito (apesar da transcrição ortográfica com hífen) paralelamente ao que acontece no segundo membro da estrutura coordenada.

(i) Tento-lhe explicar e lhe informar sobre as coisas. (Bazenga 2019: 745)

(ii) eu não gostava dele nem lhe ver à frente. (Bazenga 2019: 745). 
A presença da próclise em oraçóes infinitivas sem preposição, ou com a preposição $a$, no português europeu, não tem merecido menção na literatura, mas não é estranha ao ouvido de qualquer linguista interessado na sintaxe dos clíticos, sem que tenha de viajar até aos Açores ou à Madeira (cf. acima as frases (3a-d)). ${ }^{27}$ Já a próclise nos complexos verbais com gerúndio e, sobretudo, com o particípio passado, é mais surpreendente. ${ }^{28}$ Antes de prosseguir com alguns comentários a estas estruturas, vejamos uma amostra de frases retiradas do corpus: em (36), exemplos de próclise ao infinitivo não preposicionado (simples e flexionado); ${ }^{29}$ em (37), exemplos de próclise ao infinitivo introduzido pela preposiçáo $a$ (simples e flexionado); em (38), exemplos de próclise ao gerúndio; e em (39), o exemplo único de próclise ao particípio passado (mas veja-se a nota 27).

(36) a. Depois também eu fiquei, das pernas, que estou muito doente das minhas pernas, eu nem posso me ajoelhar. Ando. Andar, ando; mas me ajoelhar e a coisa, não. PST10

27. Exemplifica-se a próclise ao infinitivo com uma frase retirada de uma mensagem de email e duas frases de produçáo oral espontânea, ouvidas na regiáo de Lisboa. As frases pertencem a mulheres de diferentes geraçôes e níveis de escolaridade, sendo a autora da mensagem de email de onde foi extraída a frase (i) licenciada.

(i) Estava a tentar me recordar se o pedido do relatório nos havia chegado formalmente (28.04.2020)

(ii) Ontem cheguei aqui e a minha vontade era me ir embora outra vez. (s/d)

(iii) Até dá pena se comer. (04.09.2016)

Em momento posterior à redaçáo original desta nota de rodapé, tomei conhecimento de que a mulher licenciada que produziu a frase (i), e outras igualmente com próclise ao infinitivo, é afinal natural de Câmara de Lobos. Produz igualmente frases com próclise ao particípio passado, como (iv), também de uma mensagem de email. Note-se, porque é relevante, que usa consistentemente mesóclise com o futuro e o condicional nos contextos estruturais tipicamente enclíticos, o que demonstra que em (iv) o clítico está efetivamente cliticizado ao particípio passado.

(iv) Terá me escapado o seu parecer quanto ao concurso (...)? (03.07.2020)

28. Além do exemplo de próclise ao particípio passado em (27), aponto este outro de um jornalista português:

(i) A GNR acrescentou que na sequência deste caso foi alterada a política de privacidade da página oficial desta força no Facebook, sendo ativada a opçáo "aprovaçáo de identificaçóes" que antes se encontrava desativada, tendo também se acedido à opçáo de bloqueio de parceiros "onde foi bloqueada a página do Movimento Zero, por forma a que este tipo de situaçóes não voltem a ocorrer". (Expresso online, 19.02.2021, Hugo Franco)

29. Quando o clítico se posiciona entre dois verbos, como na primeira ocorrência de (36a), a ortografia do CORDIAL-SIN indica próclise quando foi essa a perceçáo tanto da transcritora como da revisora da transcrição. Acresce em alguns casos, como no exemplo em análise, que se houvesse subida do clítico a informante o colocaria em próclise, não em ênclise, ao verbo finito. É possível afirmá-lo analisando toda a produçáo da informante e verificando o padrão de colocação dos pronomes clíticos que a caracteriza. A frase foi produzida pela informante feminina da Camacha. 
b. Náo posso então lhe explicar. PIC09

c. se a gente não andar sobre ela, ela fecha tudo e não deixa a banana se criar CDR02

d. Era raro se lavrar mais de uma vez para se semear o milho. CRV64

e. E era preciso elas se darem uma com a outra. FLF21

a. E depois aquilo a gente ali todo o dia ali a remar, ali a se transpirar, puxava-se, matava-se as baleias, vinha-se para a fábrica. CLC28

b. Essa senhora custava-se a se sentar na água GRC37

c. Bota-se a carne ali, naquela água, a ela náo ficar muito encostada - náo sabe? -, a ficar a se poder mexer bem. FLF64

d. Ia trabalhar por conta de meu pai e depois calhou a ele me ensinar e fiquei a fazer alguma coisa. GRC25

e. Com uma chucha, chegam a se criarem em casa. FLF66

(38) a. Sempre me tratando. O Senhor Doutor já me quis operar dos joelhos mas eu não quis. PST10

b. E depois é que ele à maneira que a gente se foram casando é que foram se montando... MIG04

c. Vamos mexendo aquilo dois, três dias, de manhã e à noite, vai sempre se mexendo. PIC07

d. Tem dois paus atrás que estavam se fazendo a cruz. FLF20

(39) Meu pai é que foi lá, e disse por qual a razão que tinha me mandado da escola. CLC11

Nas estruturas infinitivas, tanto a flexão como a presença da preposição $a$ fazem subir a percentagem de próclise que, no entanto, náo precisa nem de uma nem de outra para ocorrer, como se vê em (36a-b). Ou seja, a próclise ocorre nos complexos verbais com infinitivo, tal como nos complexos verbais com gerúndio. Nestes últimos, a posição do advérbio bem na frase (40) indica que o verbo se move menos do que na variedade padrão - onde bem, que marca a fronteira do SV, ocorreria necessariamente depois de fervendo. ${ }^{30}$ Isto poderá ser um indicador de uma maior defetividade estru-

30. Um revisor pergunta relativamente a (40): "Couldn't bem be interpreted as an intensifier for the gerund rather than a manner adverb, thus not indicating the VP-margin? If the adverb were a negative one (e.g., mal), which fails to act as an intensifier, this would clearly indicate that the verb has not left the VP, as the author claims". No corpus não ocorrem outros advérbios que permitam testar se há ou não movimento do verbo na estrutura relevante. No entanto, como intensificador, o advérbio bem é igualmente pós-verbal no português europeu como, por exemplo, em: Eu sei/entendo bem o que queres dizer. A palavra bem pode ser ainda um marcador de ênfase, sendo neste caso pré-verbal e desencadeadora de próclise (Martins 1994, 2013). Mas, como marcador enfático, bem fica despojado do seu valor semântico básico, ao mesmo tempo que adiciona um comentário do falante (em geral, a expressão de uma atitude crítica) ao valor denotativo da frase, o que náo convém à interpretação da frase (40). 
tural das oraçôes não finitas nos dialetos açorianos e madeirenses, resultando a próclise de o verbo ocupar na estrutura da frase posiçóes mais baixas do que na variedade padrão. ${ }^{31}$ A hipótese de estruturas funcionalmente mais reduzidas parece, contudo, contraditória com o facto de o clítico não subir com verbos de reestruturação, como poder em (36a-b) (cf. Gonçalves 1999). Os dados são insuficientes para suportar uma proposta de análise, mas talvez nestes dialetos os clíticos tenham condições de legitimação por categorias funcionais diferentes das da variedade padrão.

(40) E depois de as couves estarem bem fervendo, póe-se então - então tem também um bocadinho de batata da terra, também. STE20

Nos Açores, tanto nos complexos verbais com infinitivo como com gerúndio, os clíticos ocorrem igualmente em ênclise ao verbo não finito (no segundo caso uma opção excluída na variedade padrão, embora atestada na escrita jornalística e literária). E para complicar o quadro, a subida do clítico também ocorre. Uma e a outra possibilidade exemplificam-se com o gerúndio, começando pela ênclise, em (42). Das onze ocorrências de complexos verbais com gerúndio nos Açores (uma com estar, nove com ir), quatro apresentam subida e sete cliticização ao gerúndio, quatro em próclise e três em ênclise. É de notar que a subida do clítico nos complexos verbais com gerúndio se atesta exclusivamente nas Flores, como se exemplifica em (42). Nas Flores também há próclise ao gerúndio, como se vê em (38d), mas com o auxiliar estar, enquanto as quatro ocorrências de subida do clítico são todas com ir (nas Flores, ' dir'). Isto sugere que os dados não são intratáveis, apenas lacunares, só nos deixando preencher algumas partes do puzzle. A outra localidade dos Açores em que vemos duas colocaçóes possíveis para o clítico nos complexos verbais com gerúndio é o Pico, onde o clítico não sobe, mas cliticiza ao verbo no gerúndio ora em próclise ora em ênclise. Sugerirei mais adiante possíveis motivações para este tipo de variação.

(41) a. E hoje, esses rapazes é a mesma coisa: a baleia já está quase para morrer, fraca, mas parada em cima do mar, a gente dá a lança para os rapazes irem experimentando- $a$. PIC16

b. quando vinha das terras a gente tirava-o e ia puxando-o. CLH20

a. O fuso tinha uns ganchos de se 'dir' botando o fiado FLF25

b. Pega-se com a mão e com a outra vai-se ceifando. FLF39

Relativamente à variação entre próclise e ênclise ao infinitivo, é muito claro nos Açores, onde o número total de ocorrências é mais expressivo, que há um contraste entre o clítico acusativo de terceira pessoa e os restantes clíticos. Enquanto estes não

31. Ainda que posiçóes diferentes nos complexos verbais com infinitivo e com gerúndio, já que com o infinitivo o advérbio bem ocorre depois do verbo no corpus. 
mostram preferência assinalável por uma das posiçóes, o clítico acusativo é muito maioritariamente enclítico, o que nos remete para factos bem conhecidos do português brasileiro (cf. Nunes 1993, 2019; Schei 2003). Das 98 ocorrências de cliticização ao infinitivo não preposicionado, 73 são do clítico acusativo de terceira pessoa e 25 de outros clíticos (se, the , me, te). Confirmando a tendência para a encliticização, só uma das catorze ocorrências de próclise é do clítico acusativo de terceira pessoa. A mesma tendência se observa nas oraçôes infinitivas introduzidas pela preposição $a \mathrm{e}$ ainda mais notoriamente nos complexos verbais com gerúndio. É o clítico acusativo de terceira pessoa que se vê nas três ocorrências de ênclise ao gerúndio em complexos verbais, mas não aparece em nenhuma das quatro ocorrências de próclise.

Das oraçôes infinitivas não está excluída a duplicação do clítico, como em (43). ${ }^{32}$

\section{Chega a se estragar-se. GRC38}

A frase (43) mostra-nos que a regra pós-sintática de reduplicação/metátese (Harris e Halle 2005; Magro 2007) também se aplica nas oraçôes infinitivas, podendo, portanto, inverter a ordem inicial clítico-verbo. Logo, algumas colocaçóes enclíticas poderão resultar deste processo morfológico, encobrindo o que nalgumas áreas dialetais poderá ser uma sintaxe tipicamente proclítica em domínios não finitos. Mas esta é uma hipótese que a insuficiência dos dados disponíveis apenas nos permite apontar. Em todo o caso, parece-me relevante lembrar que a próclise em domínios não finitos está bem representada no português angolano, que não tem a próclise generalizada do português brasileiro. Os exemplos que se seguem são retirados de Mutali (2019) e pertencem aos escritores angolanos, falantes nativos do português, Ondjaki (Luanda, 1977) - Os da Minha Rua, Os Transparentes - e Pepetela (Benguela, 1941) - A Sul. O Sombreiro. Nas três obras destes autores estudadas por Mutali (2019), as percentagens de próclise $v$ s. ênclise em domínios não finitos são as que se mostra na tabela $14 \mathrm{e}$ comprovam o peso muito significativo da próclise. ${ }^{33}$

32. A reduplicação ocorre também numa oração infinitiva introduzida pela preposição sem e a interpolação em infinitivas introduzidas por para, como exemplificado abaixo.

(i) Sem lhe cortar-lhe a cabeça, ela está sempre mexendo, sempre mexendo, sempre. MIG4

(ii) Um garnel para the eles não foçar. MIG09

(iii) E depois ia-se ao lameiro, botava-se aquilo num remendo para se então untar toda, toda, toda, para ficar ali. STE01

33. Mutali (2019: 117) propõe a escala de expansão da próclise no português angolano que se apresenta em (i), com as oraçóes infinitivas a revelarem-se o contexto mais permeável à mudança. O paralelismo com os dialetos açorianos e madeirenses limita-se aos domínios não finitos

(i) Infinitivas com preposição > Infinitivas sem preposição > Finitas não V1 > Finitas V1/Gerúndio > Particípio Passado 
(44) a. então menti que o meu pai estava maldisposto e eu não tinha conseguido lhe acordar. (Os da Minha Rua)

b. - podem só me devolver a chave do cadeado? (Os Transparentes)

c. Por acaso a camarada professora de português era bem porreira e nunca chegámos a lhe alcunhar. (Os da Minha Rua)

d. A culpa é da mãe, sempre a lhe meter ideias na cabeça. (A Sul. O Sombreiro)

e. A ideia era evitar Luanda e nos metermos pelo Kongo. (A Sul. O Sombreiro)

f. Se era para matar, porquê terem tanto trabalho a nos trazerem aqui? (A Sul. O Sombreiro)

g. "por mais que eu faça, não adianta, você nem nota, minha existência; e os dias passam correndo, vou acabar te perdendo, e os dias passam correndo, vou acabar te perdendo...». (Os da Minha Rua)

h. Não perdera o ar preocupado, mas relaxou um pouco, se recostando para trás na cadeira. (A Sul. O Sombreiro)

i. Por alguma razão o meu pai ainda não tinha me chamado para eu vir provar. (Os da Minha Rua)

j. fecha o jornal que já tou arrependido de ter te mostrado essa merda (Os Transparentes)

\begin{tabular}{|c|c|c|c|c|c|c|c|}
\hline & INFINITIVO & A-INFINITIVO & $\begin{array}{l}\text { INFINITIVO } \\
\text { FLEXIONADO }\end{array}$ & $\begin{array}{l}\text { A-INFINITIVO } \\
\text { FLEXIONADO }\end{array}$ & GERÚNDIO & $\begin{array}{c}\text { PARTICÍPIO } \\
\text { PASSADO }\end{array}$ & TOTAL \\
\hline \multirow{2}{*}{ Próclise } & $155 / 426$ & $34 / 84$ & $18 / 36$ & $9 / 10$ & $49 / 138$ & $5 / 36$ & $270 / 730$ \\
\hline & $36,4 \%$ & $40,5 \%$ & $50 \%$ & $90 \%$ & $35,5 \%$ & $13,9 \%$ & $37 \%$ \\
\hline \multirow{2}{*}{ Ênclise } & $271 / 426$ & $50 / 84$ & $18 / 36$ & $1 / 10$ & $89 / 138$ & $31 / 36$ & $460 / 730$ \\
\hline & $63,6 \%$ & $59,5 \%$ & $50 \%$ & $10 \%$ & $64,5 \%$ & $86,1 \%$ & $63 \%$ \\
\hline
\end{tabular}

Tabela 14. Próclise/Ênclise em domínios não finitos em Pepetela e Ondjaki, segundo Mutali (2019)

Por fim, chamo a atenção para a frase (45), onde o clítico parece estar proclítico não ao verbo mas à oração infinitiva preposicionada (comportando-se como projeção máxima e não como núcleo), pois precede a preposição $a$. Trata-se de um exemplo único, que eu talvez tivesse tomado por erro de produçáo se não fizesse tocar algumas campainhas. De facto, a frase (45) deixa de estar isolada quando a comparamos com dados afins. Primeiro, em (46), mostram-se atestaçôes retiradas de um romance de Ondjaki, que devo a Hilário Nambale. ${ }^{34}$ Seguem-se, em (47), exemplos do português europeu colhidos na internet, em diversas fontes, incluindo os agradecimentos de um relatório de estágio para obtenção do grau de mestre. A pesquisa, usando o Google, foi

34. Fica aqui expresso o meu agradecimento ao Hilário por ter descoberto estes dados ao realizar um trabalho no âmbito do seminário de mestrado em Linguística Histórica. 
fácil, porque me recordava de ter 'ouvido em flagrante a um homem jovem' (como diria Leite de Vasconcelos) a frase Estão sempre m'a dizer que pareço alentejano. O exemplo em (47f) foi-me enviado, com registo sonoro, por Sandra Pereira, a quem o agradeço.

(45) E ele me a chamar depressa para eu saltar para dentro do barco, e só vi a água dele, não vi... PIC34

(46) a. Tás ma seguir? (Quantas Madrugadas Tem a Noite)

b. É isso que tou ta falar, dá pra um gajo pôr dúvida: é melhor viver assim ou morrer já? (idem)

c. toma masé atenção, tou ta pôr é casos bem humanos (idem)

(47) a. São estas coisas que me revoltam. Andei eu durante mais de um ano sempre me a inscrever em todos os concursos para ter o apoio da porta 65 com tudo legal e contratos tudo correcto tudo direitinho, e nunca me atribuíram a ajuda ate que já desisti https://pplware.sapo.pt/informacao/porta-65-jovem-fraudes-obrigam-a-devolver-3-milhoes-de-euros/

b. mais uma vez muito obrigada e desculpa andarmos sempre te a melgar, mas como somos novas pré-mamas surgem $\mathrm{mt}$ duvidas https://demaeparamae.pt/forum/29804? page $=1$

c. Exacto kom a tua ajuda mas a mae...do bebe em kestao...Ri se ... e comenta "Ele é dificil eu sei" e ta sempre lhe a dar colo :s https://demaeparamae.pt/forum/como-desabituar

d. Pois e isso das sogras tem muito $\mathrm{k}$ se lhe diga!! A minha ta sempre se a meter e agora a tempos veio com uma conversa... https://demaeparamae.pt/forum/sogra-digam-se-encrenca-minha

e. Se comparas o vieira a uma dessas personagens eu comparo-te àqueles malucos que ficam a gritar na rua "arrependam-se antes que seja tarde, jesus cristo está a chegar”, ou com políticos que estão sempre se a queixar do governo e constantemente são arrasados nas eleiçôes... https://geracaobenfica.blogspot.com/2012/08/contra-os-idiotas-parabens-vieira-e.html?m=1

f. Quando é o próprio estado me a dizer não podes, para mim é contraditório. (Linha da Frente, RTP1, 21:16m, 11.03.2021, Lina Lourenço) https://www.rtp.pt/play/p8165/e530342/linha-da-frente

Os dados apresentados nesta secção fazem-me voltar a uma ideia que já expus em trabalhos anteriores. O sistema de colocação dos pronomes clíticos no português europeu é muito complexo e essa complexidade alia-se naturalmente a uma certa margem de variação, que pode ser percentualmente baixa e estável ao longo do tempo, mas pode também, em circunstâncias particulares, tornar-se mais expressiva e propiciadora de mudança. 


\section{Conclusão: variação, estabilidade e mudança linguísticas}

Os dialetos açorianos e madeirenses mostram dois tipos de variação na colocação dos pronomes clíticos, contra um pano de fundo que é o sistema de colocação dos pronomes clíticos geral no português europeu e, portanto, comum a todos os seus dialetos. Uma das facetas da variação, a ênclise atípica ao verbo finito, foi já estudada por Magro $(2007,2010)$ e os dados açorianos e madeirenses confirmam inteiramente a análise que propõe, derivando esta variante da aplicação de uma regra pós-sintática (morfológica, no quadro teórico da Morfologia Distribuída) de reduplicação/ metátese (Harris e Halle 2005). O que o presente estudo traz de novo é a observação de que a ênclise atípica pode resultar também de especificidades léxico-gramaticais (certos advérbios) e estruturais (por exemplo, as relativas cortadoras e resuntivas). Por isso, contrariamente ao que prediria a simples metátese pós-sintática, tem graus de incidência diferentes conforme o contexto sintático, numa escala que é constante através de diferentes dialetos (na base da escala estáo as frases negativas e no topo as subordinadas relativas e as frases com advérbios tipicamente proclisadores). A outra faceta da variação observada nos dialetos açorianos e madeirenses é a próclise atípica ao infinitivo, gerúndio e, mais raramente, particípio passado, a qual não mereceu até agora atenção idêntica à que foi dedicada à ênclise atípica. Os dois tipos de colocação atípica ocorrem, portanto, em domínios sintáticos disjuntos (a primeira nas frases finitas e a segunda nas não finitas) e não há correlação entre os dois tipos de fenómeno. Nos dialetos estudados, a localidade com menor presença da ênclise atípica (a Camacha, na ilha de Porto Santo) tem a expressão mais forte da próclise atípica. Além disso, a próclise atípica parece ser um fenómeno propriamente sintático (e não pós-sintático), ainda que os dados disponibilizados pelo CORDIAL-SIN sejam insuficientes para avançar uma hipótese de análise formal. Interessantemente, a próclise atípica dos dialetos portugueses tem correlatos em variedades não europeias do português, o que náo parece acontecer com a ênclise atípica, cujas instanciaçóes alternativas são a interpolação e a duplicação do clítico. Sendo embora fenómenos distintos, próclise atípica e ênclise atípica não são incompatíveis, podendo coexistir e cruzar-se no mesmo dialeto. De facto, nos dialetos que admitem os dois tipos de atipicidade, os proclíticos das orações infinitivas podem alterar a sua posição relativamente ao verbo como resultado da aplicação da regra de reduplicação/metátese, independentemente de serem casos de próclise típica ou atípica. Este facto constitui evidência adicional de que a próclise atípica é derivada na sintaxe.

$\mathrm{Na}$ comparação entre os dialetos estudados, vemos o arquipélago dos Açores a mostrar percentagens de ocorrência relativamente baixas, ainda que significativas, das colocaçôes atípicas e uma certa homogeneidade interna que, embora deixe margem para casos de microvariação, não configura sub-regiốes. No arquipélago da Madeira, pelo contrário, emerge uma separação clara entre a ilha da Madeira (representada no 
CORDIAL-SIN por Câmara de Lobos e Caniçal) e a ilha de Porto Santo (representada sobretudo pela informante feminina da Camacha). ${ }^{35} \mathrm{~A}$ ilha da Madeira destaca-se pela elevada percentagem de ocorrências de ênclise atípica. Poderá pensar-se que o sistema de colocação dos clíticos está, nas localidades em causa, a mudar? A minha resposta cautelosa é "não", porque qualitativamente nada de significativo distingue os dados da ilha da Madeira dos dados dos outros dialetos. O que vemos é a regra de reduplicação/metátese a ser mais produtiva (e mais restritiva porque não deriva a interpolação) na ilha da Madeira. Mas sendo uma regra pós-sintática, ainda que a sua produtividade aumente continuará a ser compatível com a derivação na sintaxe daquilo que é o padrão geral de colocação dos clíticos no português europeu. Acresce que, possivelmente, a sintaxe das oraçóes relativas e especificidades de alguns advérbios serão responsáveis por uma boa parte da ênclise atípica observada na Madeira. E quanto à próclise atípica? Temos 100\% de ocorrências em Porto Santo, mas em números absolutos são meia dúzia de atestaçôes, o que não nos autoriza a retirar conclusôes. Ainda assim, parece-me relevante a comparação com o português angolano, onde se assiste a uma mudança em curso na direção da próclise que parece ter maior incidência nos domínios não finitos (cf. nota 32). Não quero com isto dizer, claro, que tenha a expectativa de que o português de Porto Santo venha a mudar similarmente ao português angolano. O que quero dizer é que o sistema de colocação dos pronomes clíticos no português europeu é compatível com margens de variação que, independentemente de serem mais residuais ou mais expressivas, podem manter-se estáveis ao longo do tempo ou, pelo contrário, quando abaladas no seu equilíbrio natural por fatores externos, ser o fermento de mudanças. Até agora, a história do português fora da Europa só demonstra que pode evoluir no sentido da expansão e generalização da próclise.

35. Cf. Brissos, Gillier e Saramago (2016). Neste artigo, a partir de um estudo do léxico numa perspetiva dialetométrica, os autores concluem que "a variação lexical madeirense não é dispersa, distribuindo-se antes de forma coerente, nomeadamente na distinção centro-oriente da ilha da Madeira versus ocidente da ilha da Madeira + Porto Santo". 


\section{Agradecimentos}

O meu sincero agradecimento pelos comentários e sugestóes de dois revisores anónimos.

\section{Financiamento}

Este trabalho foi financiado por fundos nacionais através da FCT - Fundação para a Ciência e a Tecnologia, I.P., no âmbito dos projetos UIDB/00214/2020 e SynAPse, PTDC/LLT-LIN/32086/2017.

\section{Corpus}

Martins, Ana Maria (coord.). 2000-. CORDIAL-SIN: Corpus Dialectal para o Estudo da Sintaxe / Syntax-oriented Corpus of Portuguese Dialects. CC licensed: CORDIAL-SIN by Centro de Linguística da Universidade de Lisboa. http://clul.ulisboa.pt/recurso/cordial-sin-syntax-oriented-corpus-portuguese-dialects 


\section{Referências bibliográficas}

Álvarez, Rosario \& Xosé Xove. 2002. Gramática da Lingua Galega. Vigo: Galaxia.

Bazenga, Aline. 2019. Aspetos da Sintaxe do português popular falado no Funchal. Arquivo Histórico da Madeira, Nova Série, n. ${ }^{\circ}$ 1, 727-758.

Bonet, Eulàlia. 2002. Cliticització. Em Joan Solà, Maria Rosa Lloret, Joan Mascarò \& Manuel Pérez Saldanya (eds.), Gramàtica del català contemporani. Volum 1: Introducció, Fonética i fonologia, Morfologia. 933-989. Barcelona: Empúries.

Brissos, Fernando, Raïssa Gillier \& João Saramago. 2016. O problema da subdivisão da variedade dialetal madeirense: estudo dialetométrico da variação lexical, en Textos Selecionados. XXXI Encontro Nacional da Associação Portuguesa de Linguistica. 31-47. Porto: FLUP / APL. [= Revista da Associação Portuguesa de Linguistca 2, URL: http://ojs.letras.up.pt/index.php/APL/issue/ view/116]

Cardoso, Adriana \& Nélia Alexandre. 2013. Relativas clivadas em variedades não standard do português europeu. Em Fátima Silva, Isabel Falé \& Isabel Pereira (eds.), Textos Selecionados do XVIII Encontro Nacional da Associação Portuguesa de Linguistica. 205-227. Porto: APL.

Carrilho, Ernestina. 2005. Expletive Ele in European Portuguese Dialects. Tese de doutoramento. Faculdade de Letras da Universidade de Lisboa. http://clul.ulisboa.pt/sites/default/files/tese/carrilho_2005.pdf

Duarte, Inês. 2003. Padrôes de colocação dos pronomes clíticos. Em Maria Helena Mira Mateus, Ana Maria Brito, Inês Duarte \& Isabel Hub Faria (eds.), Gramática da Lingua Portuguesa. 847-867. Lisboa: Caminho.

Fernández-Rubiera, Francisco José. 2009a. Clitics at the Edge: Clitic Placement in Western Iberian Languages. Washington, DC: Georgetown University. Tese de doutoramento inédita.

Fernández-Rubiera, Francisco José. 2009b. Another look at the [+finite] subordinate context in Western Iberian Romance. Revista de Filoloxía Asturiana 6/7/8, 289-309.

Fernández-Rubiera, Francisco José. 2010. Force ${ }^{\circ}$, Finiteness ${ }^{\circ}$ and the placement of clitics in Western Iberian Romance languages. Estudos de Lingüistica Galega 2, 75-95.

Gonçalves, Anabela. 1999. Predicados Complexos Verbais em Contextos de Infinitivo não Preposicionado do Português Europeu. Tese de doutoramento inédita. Faculdade de Letras da Universidade de Lisboa.

González i Planas, Francesc. 2007. Sintaxis de los clíticos pronominales en asturleonés. Ianua. Revista Philologica Romanica 7, 15-35.

Gutzmann, Daniel, Katharina Hartmann \& Lisa Matthewson. 2020. Verum focus is verum, not focus: Cross-linguistic evidence, Glossa: a journal of general linguistics 5(1), 51. https://doi.org/10.5334/ gigl.347

Harris, James \& Morris Halle. 2005. Unexpected Plural Inflections in Spanish: Reduplication and Metathesis, Linguistic Inquiry 36.2, 195-222. https://doi.org/10.1162/0024389053710710

Höhle, Tilman N. 1992. Über Verum-Fokus im Deutschen. Em Joachim Jacobs (ed.), Informationsstruktur und Grammatik. 112-141. Opladen: Westdeutscher Verlag. https://doi.org/10.1007/9783-663-12176-3_5 
Lohnstein, Horst. 2016. Verum focus. Em Caroline Féry \& Shinishiro Ishihara (eds.), The Oxford handbook of information structure. Oxford Handbooks Online. Oxford: Oxford University Press. https://doi.org/10.1093/oxfordhb/9780199642670.013.33

Magro, Catarina. 2007. Clíticos: variaçóes sobre o tema. Tese de doutoramento. Faculdade de Letras da Universidade de Lisboa. https://repositorio.ul.pt/handle/10451/6083

Magro, Catarina. 2010. Interpolação \& Cia. nos dialectos do Português Europeu, Estudos de Lingüistica Galega 2, 97-119. https://doi.org/10.3309/1989-578X-10-5 / https://revistas.usc.gal/index. php/elg/article/view/1510

Martins, Ana Maria. 1994. Clíticos na História do Português. Tese de doutoramento. Faculdade de Letras da Universidade de Lisboa.

Martins, Ana Maria. 2009. Subject doubling in European Portuguese dialects: the role of impersonal se. Em Enoch O. Aboh, Elisabeth van der Linden, Josep Quer \& Petra Sleeman (eds.), Romance Languages and Linguistic Theory. Selected papers from 'Going Romance' Amsterdam 2007. 179-200. Amsterdam/Philadelphia: John Benjamins.

Martins, Ana Maria. 2013. Posição dos pronomes pessoais clíticos”. Em Eduardo B. Paiva Raposo, Maria Fernanda Bacelar, Maria Antónia Mota, Luísa Segura \& Amália Mendes (eds.), Gramática do Português. 2231-2302. Lisboa: Fundação Calouste Gulbenkian.

Martins, Ana Maria. 2016. A colocação dos pronomes clíticos em sincronia e diacronia. Em Ana Maria Martins \& Ernestina Carrilho (eds.), Manual de Linguistica Portuguesa. 401-430. Berlin/ Boston: De Gruyter.

Mutali, Henrique Simão. 2019. A colocação dos pronomes clíticos no português angolano escrito. Tese de mestrado. Faculdade de Letras da Universidade de Lisboa. https://repositorio.ul.pt/bitstream/10451/40812/1/ulfl274272_tm.pdf

Nunes, Jairo. 1993. Direçáo de cliticização, objeto nulo e pronome tônico na posição de objeto no português brasileiro. Em Ian Roberts \& Mary A. Kato (eds.), Português Brasileiro: Uma Viagem Diacrônica. 207-222. Campinas, SP: Editora da Unicamp.

Nunes, Jairo. 2004. Linearization of Chains and Sideward Movement. Cambridge, MA: MIT Press.

Nunes, Jairo. 2019. Clíticos acusativos de terceira pessoa em português brasileiro como concordância de objeto. Em Charlotte Galves, Mary A. Kato \& Ian Roberts (eds.), Português Brasileiro: Uma Segunda Viagem Diacrônica. 151-172. Campinas, SP: Editora da Unicamp.

Paradis, Anna. 2019. L'ascens dels clítics. Tese de doutoramento. Universitat Autònoma de Barcelona.

Schei, Ane. 2003. Algumas observaçóes sobre a colocação dos pronomes clíticos no português brasileiro falado, Studia Neophilologica 75.1, 58-70. https://doi.org/10.1080/0039327031000641 